NBER WORKING PAPER SERIES

\title{
THE EFFECTS OF FOREIGN-BORN PEERS IN US HIGH SCHOOLS AND MIDDLE SCHOOLS
}

\author{
Jason Fletcher \\ Jinho Kim \\ Jenna Nobles \\ Stephen Ross \\ Irina Shaorshadze \\ Working Paper 26491 \\ http://www.nber.org/papers/w26491
}

\author{
NATIONAL BUREAU OF ECONOMIC RESEARCH \\ 1050 Massachusetts Avenue \\ Cambridge, MA 02138 \\ November 2019
}

This research uses data from Add Health, a program project directed by Kathleen Mullan Harris and designed by J. Richard Udry, Peter S. Bearman, and Kathleen Mullan Harris at the University of North Carolina at Chapel Hill, and funded by grant P01-HD31921 from the Eunice Kennedy Shriver National Institute of Child Health and Human Development, with cooperative funding from 23 other federal agencies and foundations. Special acknowledgment is due Ronald R. Rindfuss and Barbara Entwisle for assistance in the original design. Information on how to obtain the Add Health data files is available on the Add Health website (http://www.cpc.unc.edu/ addhealth). No direct support was received from grant P01-HD31921 for this analysis. The authors thank Eric Grodsky, Christine Schwartz, and the William T. Grant Foundation for research support for this project. The views expressed herein are those of the authors and do not necessarily reflect the views of the National Bureau of Economic Research.

At least one co-author has disclosed a financial relationship of potential relevance for this research. Further information is available online at http://www.nber.org/papers/w26491.ack

NBER working papers are circulated for discussion and comment purposes. They have not been peer-reviewed or been subject to the review by the NBER Board of Directors that accompanies official NBER publications.

(C) 2019 by Jason Fletcher, Jinho Kim, Jenna Nobles, Stephen Ross, and Irina Shaorshadze. All rights reserved. Short sections of text, not to exceed two paragraphs, may be quoted without explicit permission provided that full credit, including $\odot$ notice, is given to the source. 
The Effects of Foreign-Born Peers in US High Schools and Middle Schools

Jason Fletcher, Jinho Kim, Jenna Nobles, Stephen Ross, and Irina Shaorshadze

NBER Working Paper No. 26491

November 2019

JEL No. I1,I12,I14,I24,J1,J15,J24

\begin{abstract}
$\underline{\text { ABSTRACT }}$
The multi-decade growth and spatial dispersion of immigrant families in the United States has shifted the composition of US schools, reshaping the group of peers with whom students age through adolescence. US-born students are more likely to have foreign-born peers and foreignborn students are more likely to be educated outside of enclaves. This study examines the shortterm and long-term impact of being educated with immigrant peers, for both US-born and foreign-born students. We leverage a quasi-experimental research design that uses across-grade, within-school variation in cohort composition for students in the Add Health study. We describe effects on a broad set of education, social, and health outcomes. For US-born students, we find little evidence that having immigrant peers affects a wide array of outcomes, either in adolescence or in adulthood. For foreign-born students, attending school with other immigrant students is protective against risky health behaviors and social isolation, relative to native born students. However, foreign-born students' language skills measured with Picture-Vocabulary Test scores are negatively affected by attending school with a larger share of other immigrant students. The negative effect on vocabulary scores persists through young adulthood but does not translate into reductions in most longer-run socioeconomic outcomes, including earnings or the economic status of their residential neighborhoods.
\end{abstract}

Jason Fletcher

University of Wisconsin-Madison

La Follette School of Public Affairs

1225 Observatory Drive

Madison, WI 53706

and NBER

jfletcher@lafollette.wisc.edu

Jinho Kim

Department of Sociology

The Chinese University of Hong Kong

Shatin, NT

Hong Kong

jinho.kim@cuhk.edu.hk

Jenna Nobles

University of Wisconsin, Madison

1180 Observatory Drive

Madison, WI 53706

jnobles@ssc.wisc.edu
Stephen Ross

University of Connecticut

Department of Economics

341 Mansfield Road, Unit 1063

Storrs, CT 06269-1063

stephen.1.ross@uconn.edu

Irina Shaorshadze

University of Wisconsin

shaorshadze@wisc.edu 


\section{INTRODUCTION}

Many domains of adolescent life are shaped by the behaviors and attributes of school-aged peers. Peers influence academic performance, health-related behaviors, socioemotional development, and even criminal activity (Billings, Deming, and Ross forthcoming; Burke and Sass 2013; Duncan et al. 2005; Eren 2017; Gavira and Raphael 2001; Kao 2001; Ream and Rumberger 2008; Wodtke and Parbst 2017). As a result, the composition of adolescents' schools—and the attendant formation of students' peer relationships—is an important pathway through which education experiences influence socioeconomic and socioemotional development. Studies of classroom and grade-level composition highlight a number of potentially relevant traits among students' peers, including familial social capital, racial composition, and language skills (Bifulco et al. 2011; Gamoran, Collares, and Barfels 2016; Fletcher 2010; Levy and Schlosser).

In recent years, the multi-decade growth and spatial dispersion of immigrant families in the U.S. has brought questions of school composition into public debate. In 1980, eight U.S. states had public school systems in which at least one-tenth of students came from immigrant households. By 2000, this was true of twenty U.S. states, and by 2015, thirty-two U.S. states (Camarota et al. 2017). By 2000, 20\% of U.S. counties had immigrant population shares that exceeded 5\% (Census Bureau 2017). The composition of school districts has changed over the last thirty years—shifting toward a growing share of primary and secondary schools in which foreign-born and US-born students attend school together.

For US-born students, the effects of attending school with a growing share of immigrant students are a priori ambiguous. Though sometimes portrayed otherwise, foreign-born adolescents exhibit fewer risk behaviors, better health behaviors, and fewer behavioral problems than their US-born peers (Harris 1999; Chin and Bleakley 2004), with some variation across group and across place. To the extent that peer effects operate through behavioral modeling, attending school with a larger share of foreign-born students may have positive externalities on other students' welfare. At the same time, concerns have been raised about possible academic detriments of attending schools with a larger share of foreign-born students, largely because of English language learning needs. Evidence on academic assessments is mixed, though most studies have focused on short-run testing outcomes (Conger 2015; Crosnoe and Lopez-Gonzalez 2005; Diette and Oyelere 2014). 
For immigrant students, attending schools with large shares of US-born students may similarly influence multiple domains of well-being. Schools are sites of socialization and network formation. Adopting the health or risk behaviors of US-born peers may worsen long-run outcomes for the foreign-born (Harris 1999; Antecol and Bedard 2006). At the same time, social ties to US-born students and their families could generate forms of upward socioeconomic mobility for immigrant students from less wealthy families (Gandara et al 2009; Ream 2010). Schools can also be sites of harassment and discrimination (Salerno and Reynolds 2016; Silver 2015); larger shares of US-born students may create environments that worsens the mental health and academic performance of students from immigrant families. This may be exacerbated if the share of foreign-born students in a school is mirrored in the background of the teaching staff_-or more broadly, the institution’s preparedness to work with immigrant families (Gandara 2010). The schooling environments of immigrant youth in "new destination" regions, i.e., areas with a relatively recent history of foreign-born residents, has appropriately received attention (Potochnick 2014; Spees, Pereira, and Fuglini 2016).

A key challenge in estimating the effects of peer traits—on both US-born and foreignborn students - is that causal attribution is difficult. The composition of students' peers is a complicated function of multiple factors that sort students into schools, like neighborhood home prices, proximity to employment sources, and parental ability to invest in schooling quality. Taking advantage of an approach developed by Hoxby (2000), and elaborated by others (Bifulco et al. 2011; Hanushek et al. 2003; Vigdor and Nechyba 2007), several studies have used comparisons across grades within schools to characterize the effects of attending schooling with foreign-born peers on measures captured in administrative data: matriculation, grades, and test scores (Conger 2015; Hardoy et al. 2018; Hermansen and Birkelund 2015). These measures provide an important assessment of intermediate education outcomes. Qualitative evidence suggests, however, that school peer effects may shape many other aspects of adolescent development that are relevant for long-run wellbeing.

In this study, we investigate a comprehensive set of schooling and developmental outcomes for a large cohort of foreign-born and US-born adolescents in schools spread across the United States. We measure multiple domains while students are in school. In addition to identifying peer composition effects on standardized language vocabulary tests, we study effects on measures of social acceptance, social participation, mental health, risk behaviors, and 
academic effort. We then follow the students forward as they age, to assess how enduring the implications of these adolescent peer effects are for long-run welfare. Our study provides a comprehensive assessment of the peer implications of migration-driven changes to school composition. In so doing, the findings contribute to recent discussions about the presence of migrant families in communities across the U.S.

We observe little evidence that the share of foreign-born students in adolescents' grades negatively affects the adolescent measures of wellbeing among their US-born classmates. By contrast, the effects of school composition on foreign-born students relative to native born students are meaningful in size and vary across domains. Compared to native students, immigrant students express more social acceptance, better mental health, increased academic effort and reduced participation in risk behavior when their peers are composed of more foreign-born students.

Their scores on standardized assessments in the Picture-Vocabulary Test (PVT) are worse, however. These effects tend to be smaller when the school immigrant population is more similar to the focal student in terms of racial and ethnic composition, consistent with peer effects requiring some threshold number of similar individuals with which to form friendships.

However, for mental health and academic effort, we are unable to distinguish between situations where there are positive peer effects for foreign-born students or where there are negative (but noisily estimated) peer effects for native-born students and negligible effects for foreign-born students. All of these effects operate net of the confounding variation that sorts students into schools.

When we follow a sub-set of the students into adulthood, we find little evidence among U.S. born students of detrimental effects of attending school with foreign-born students on completed schooling, health risk behaviors, mental health, or residential environment in adulthood. Among foreign-born students, we find no evidence that the protective effects of enclaves in adolescence persist into adulthood. Instead, only the negative effects of attending school with a larger share of foreign-born students on the PVT scores and an additional reduction in years of schooling remains as the students enter adulthood.

In sum, we find no statistically significant evidence that the late-twentieth century expansion of migrant families into school districts across the U.S. had a deleterious impact on a wide array of outcomes measured among US-born students, either in adolescence or in 
adulthood. If anything, the only meaningfully sized harmful effect we detect is for foreign-born students, whose language skills develop more favorably in adolescence and into adulthood in schools with larger shares of US-born students. That protective enclave effects observed in adolescence do not translate into better measures of adult welfare underscores the value of studying movement into adulthood as an important transition period shaping outcomes among the foreign-born in the U.S. (Gonzales 2015).

\section{SCHOOL COMPOSITION AND WELLBEING IN ADOLESCENCE AND ADULTHOOD}

Social science provides a long history of research on the effects of the school environment, both on student development generally (Wang and Holcombe 2010; Reyes et al. 2012) and on the development of immigrant students in particular (Stanton-Salazar 1995; Ream 2010). Models of immigrant incorporation in adolescence emphasize the importance of the local "context of reception," in which the school environment is a key site of socialization (Portes and Zhou 1993; Zhou 1997).

For some outcomes of adolescent and adult welfare, peer composition may be a particularly important aspect of the school environment; peers shape many features of students' experiences both within and beyond the classroom (Suárez-Orozco et al. 2008; Wang and Eccles 2012). In the present study, we focus on a broad set of outcomes—standardized test scores, academic effort, risk behaviors, social acceptance, and mental health in adolescence. In adulthood, we measure outcomes that plausibly extend from these — earnings, education, health behavior, criminal activity, mental health, and even features of individuals' residential context.

Multiple mechanisms suggest a plausible link between the composition of students' peers and their socioeconomic and socioemotional development: behavioral modeling; effects on classroom content and pacing of learning; student experiences of inclusion or exclusion; and formation of network ties that may develop or hinder socioeconomic mobility.

Peer effects that operate through the adoption of academic, risk-taking, and health-related behaviors may advantage students attending school with a larger share of immigrants. Foreignborn adolescents, on average, engage in less risky behaviors_including alcohol and drug useand better health-promoting behaviors-including diet and exercise-relative to their US-born peers (Harris 1999; Chin and Bleakley 2004). In addition, immigrant students report higher levels of academic effort than do US-born students (Peguero et al. 2016). Scholars have 
attributed this difference in part to the academic orientation of immigrant parents whose motivation for migration is often to support schooling opportunities for children (Hagelskamp et al. 2010; Suárez-Orozco, Suárez-Orozco, and Todorova 2008). Goldsmith (2003) demonstrates that the positive correlation between Latino students' test scores and share of Latino students in schools is partially attributable to the share of students with immigrant parents.

Stronger academic effort may have spillover effects that operate through pathways other than behavioral modeling too; effort among immigrant students may also contribute to the acceleration of class pacing and may raise teachers' expectations. At the same time, some have raised concerns that English language learners require a larger share of teacher attention and school resources. To date, studies have found limited evidence that attending school with foreign-born students who are English language learners has negative effects on academic performance (Conger 2015; Crosnoe and Lopez-Gonzalez 2005; Diette and Oyelere 2014). For immigrant students, the classroom spillover effects of attending school with a larger share of other foreign-born students may be positive for learning — particularly if teaching resources are tailored to the language, culture, and acclimation needs of students.

A third mechanism that links peer composition to student welfare operates by shaping how students are treated by classmates - and accordingly, how comfortable the student is inside and outside the classroom setting (Ackert 2018; Ispa-Landa 2012). A priori the effects of the relative share of foreign-born students on the receptive climate is ambiguous. Immigrant students with primarily US-born peers may feel isolated linguistically and socially. They may have fewer peers who understand the challenges of navigating cultural gaps between their home and school environments (Portes and Rumbaut 2001). They may be more regularly exposed to overt or subtle forms of racism and xenophobia by US-born peers (Salerno and Reynolds 2017); a larger share of foreign-born students may provide a protective enclave that minimizes exposure to these forms of hostility. In contrast, some scholarship indicates that anti-immigrant sentiment grows when group size is perceived as threatening (Hainmuller and Hopkins 2014). If so, school climate for immigrants may worsen with a larger share of foreign-born students.

Finally, peer effects also arise if the formation of social networks provides access to forms of education-specific or employment-specific capital. If US-born students have, on average, parents with more experience navigating the US higher education system and ties to 
better local employment opportunities, attending school with a larger share of US-born students may improve schooling and work outcomes for immigrant adolescents (Stanton-Salazar 2000).

The links between peer composition and student outcomes are undoubtedly conditioned by the extent of intra- and intergroup contact. In many high schools, the foreign-born population is a heterogeneous group, and attending school in the same grade does not necessarily imply sufficient contact to generate behavior changes or network ties. Most research on intergroup interaction in U.S. schools suggests that ethnic and racial identification shapes friendship formation (Moody 2001; Currarini, Jackson, and Pin 2010). For immigrant students who are in classes with a larger share of students from the same origin country or who, more broadly, identify as sharing a common ethnic identity, these effects may be more salient. Alternatively, it is possible that the presence of additional foreign-born students matters less for students in schools with many opportunities for finding similar peers, e.g. schools with a large share of the same-origin group or encompassing a network of second-generation native-born students. For example, if peer effects arise due to the formation of friendships, additional foreign-born peers may matter most when there are very few similar students available from which foreign-born students might form friendships. In this case, marginal peer effects would be zero where students have a large number of similar peers because the peer effects arising from the tendency towards homophilous friendships has reached it maximum. In fact, Weinberg (2013) demonstrates that with strong homophily in friendships students are likely to experience the influence of their most similar peers once the population crosses a modest size threshold because students can strategically seek out similar students within a school.

Given the long-term implications of better health in adolescence (Haas and Fosse 2008; Jackson 2010), we would expect these effects to persist into adulthood. That is, the conditions that improve students' mental health and health risk behaviors in adolescence might improve their health and economic outcomes in adulthood. Conditions that affect students' schooling attitudes and test scores should influence their likelihood of staying in school, their attendant employment outcomes, and the economic context of their neighborhoods-i.e., where they are able to live-as adults. 


\section{IDENTIFYING EFFECTS OF PEER COMPOSITION}

Estimating peer effects is complicated by several potential sources of bias (Manski 1993, Hoxby 2000). Peer composition is affected by the sorting of families across neighborhoods and into schools. If foreign-born students, on average, attend schools in less wealthy communities the unmeasured correlates of these residential patterns will be misinterpreted as the effects of peer composition. Bias may also occur when data is generated from students' reports of peer characteristics. Correlated measurement error - the tendency to report similarly positive or negative outcomes for oneself and one’s peers, for example-will upwardly bias peer effects.

To address these issues, we leverage a within-school across-cohort identification strategy with data collected from a census of students within a representative sample of U.S. high schools and middle schools. We estimate specifications that model student outcomes as a function of the composition of their cohort peers, conditional on school fixed effects. The design is motivated by an assumption: while families purposely select schools for their children, they are unlikely to select the specific cohort of students that their child will join, conditional on the school (Bifulco et al. 2011, Conger 2015). Variation in the share of foreign-born students across cohorts in a given school can be assumed to be quasi-random. We provide evidence for the validity of acrosscohort identification by presenting balancing tests. After conditioning on school fixed effects, student foreign-born status and race/ethnicity, we find at most modest and statistically insignificant correlations between peer composition and pre-determined observable characteristics of families (like maternal education). And because we use data from school censuses — students' report about themselves — we reduce potential measurement error from sampling error or reporting bias (e.g., when individual and peer schooling outcomes are reported by the same respondent).

The causal effects of attending school with smaller and larger shares of foreign-born peers have been primarily documented in settings outside the United States. This research describes intermediate education outcomes_-grade/level completion and standardized test scores. Several of these studies suggest that the presence of foreign-born peers lowers student performance on exams and rates of matriculation. Gould et al. (2009) find negative effects of immigrant students in classrooms on high school matriculation in Israel. Using PISA data in Denmark, Jensen and Rasmussen (2011) find negative effects of immigrant peers on both reading and math scores. Exploiting the rules of class formation in Italy, Ballatore et al. (2013) 
find negative effects from immigrant classroom peers on native students for the language and math scores. Tonello (2015) finds small negative effect on the Italian students' language test scores. Schneeweis (2011) uses an across-cohort within-school strategy in Austria to show adverse effects on grade repetition and track attainment for migrant students in cohorts with a large share of migrant peers. Hardoy and Schone (2013) find negative peer effects from immigrant students in the classroom in Norway. By contrast, a handful of studies on native-born students in the Netherlands (Ohinata and Van Ours 2013, 2016), England (Geay et al. 2013), and Israel (Chachashvili-Bolotin 2016) do not detect negative effects on education outcomes of attendance with immigrant peers.

Despite the large, rich literature on immigrant schooling in the US, few studies examine peer effects with strategies that address issues of confounding and measurement bias described above. Two exceptions provide arguably quasi-experimental evidence on the effects of having immigrant peers in the U.S.; both describe effects on schooling and testing outcomes. Schwartz and Stiefel (2011) use administrative data in NYC and find that the share of immigrant students at the grade level has small, negative effects on foreign-born students' math scores but no association with native-born students' math scores. Conger (2015) uses administrative data in Florida and does not find evidence that foreign born peers-including English language learners—affect their high-school classmates’ academic performance.

We build on these studies by applying a similarly rigorous strategy to the study of a much broader set of socioemotional and socioeconomic outcomes among a cohort of students from a nationally-representative sample of schools across the U.S. Unlike previous work, we follow these students into adulthood and consider the longer-run implications of cohort composition in school. In so doing, we also consider how the diversity of the foreign-born population in a given cohort shapes student wellbeing. Before turning to the data, we describe the across-cohort, within-school design in more detail. 


\section{METHOD}

\section{Approach}

We estimate a series of specifications that include the share of students with each school-specific cohort ${ }^{1}$ that is foreign-born (Eq. $1, \bar{F}_{c s}$ ) and the interaction of this share with whether the student is foreign-born $\left(\mathrm{F}_{\mathrm{i} c s}\right)$ :

$$
y_{i c s}=\beta_{0}+\beta_{1} \mathrm{X}_{i c s}+\beta_{2} \mathrm{~W}_{c s}+\beta_{3} \overline{\mathrm{F}}_{c s}+\beta_{4} \overline{\mathrm{F}}_{c s} \mathrm{~F}_{\mathrm{i} c s}+C_{c}+S_{s}+\varepsilon_{i c s}
$$

The outcome $y$ of student $i$ in cohort $c$ in school $s$ is a function of individual covariates $X_{i c s}$ including the individual student's foreign-born status, school-cohort composition over the percentage of foreign-born students $\bar{F}_{c s}$, additional school-cohort level covariates $W_{c s}$, as well as cohort and school fixed effects $C_{c}$ and $S_{s}$, and an error term $\varepsilon_{i c s}$.

We then explore heterogeneity in the peer effects captured by $\beta_{3}$ and $\beta_{4}$. Specifically, we examine whether peer effects are more or less salient when the cohort composition of foreignborn students shares ethnic background with the focal student. We do so by introducing an interaction term between the peer effect variable and a measure of how similar the school immigrant population is on racial and ethnic composition to the student's own race and ethnicity. Using a detailed measure of students' reports of race and ethnicity (described below), we measure the fraction of immigrants in each school who identify as members of group $g\left(\alpha_{g s}\right)$. For each student, we measure $L_{i s}$, the fraction of the school's immigrant students whose ethnic identification matches that of the focal student:

$$
L_{i s}=\sum_{g} \delta_{i g} \alpha_{g s}
$$

where $\delta_{i g}$ is 1 if the individual, whether immigrant or US-born, belongs to racial or ethnic group $g$ and zero otherwise. We interact this variable with the indicators that the student is foreign-born $\left(F_{i c s} L_{i s}\right)$, the share foreign-born in the cohort $\left(\bar{F}_{c s} L_{i s}\right)$ and with the product of the cohort share foreign-born and whether the student is foreign-born-creating a triple interaction $\left(\bar{F}_{c s} F_{i c s} L_{i s}\right)$.

\footnotetext{
${ }^{1}$ We use the term cohort to reference a student's grade or year in school.
} 


$$
\begin{gathered}
y_{i c s}=\beta_{0}+\beta_{1} X_{i c s}+\beta_{2} W_{c s}+\beta_{3} \bar{F}_{c s}+\beta_{4} \bar{F}_{c s} F_{i c s}+\beta_{5} \bar{F}_{c s} L_{i s}+\beta_{6} \bar{F}_{c s} F_{i c s} L_{i s}+L_{i s} \\
+F_{i c s} L_{i s}+C_{c}+S_{S}+\varepsilon_{i c s}
\end{gathered}
$$

The specification tests whether attending school with a larger share of foreign-born students has larger or smaller effects for foreign-born students if the schools' foreign-born population shares ethnic identification with the focal student.

Finally, in a supplemental analysis, we ask whether peer effects differ by key school level attributes. First, we allow the effect of foreign-born peers to be non-linear by interacting peer effects with whether the school has a share of foreign-born students that is above the median for our sample. Second, we allow peer effects to differ by whether the fraction of students whose families do not speak English at home is above the median, and whether the fraction of students whose parents are foreign-born is above median. These tests provide additional evidence about the role of language and the relevance of immigrant parents for first- and second-generation students in the studies’ findings.

\section{Data}

The National Longitudinal Study of Adolescent Health (Add Health) is a school-based longitudinal study of health and education-related behaviors of adolescents. The survey follows individuals through young adulthood by collecting information on health, behavioral and labor market outcomes. The data are nationally representative and were collected through stratified clustered sampling of schools and students. A sample of 80 high schools and 54 feeder schools was drawn across the United States through a sample frame that was stratified by region, urbanicity, school type, ethnic mix and size. Wave I of the survey was conducted between 1994 and 1995 and consisted of an In-School and an In-Home survey. The In-School survey was administered between September 1994 and April 1995 to all students present at school on the given day and so represent a virtual census of the school population, with a sample size of over 90,000 students. Subsequently, an In-Home sample of students was selected from the population of all students to be administered a more detailed survey and then to be followed longitudinally. From each school, the In-Home sample included 17 male and 17 female students from each 
grade, and this sample was enhanced through oversampling based on characteristics such as race, twin status, and disability.

We use data from the In-School Survey as well as waves I, III and IV of the In-Home surveys. The Wave I In-Home survey was conducted soon after the In-School survey between April and December 1995 and was completed by 20,745 students. The Wave III In-Home survey was conducted in 2001 and 2002 about 7 years after the original In-School survey (participants were 18 to 26 years old) and was completed by 15,197 individuals. The Wave IV survey was conducted in 2008, 14 years after the original survey (participants were 24 to 32 years old). The wave IV In-Home survey was completed by 15,701 individuals. The survey questionnaire administered in Wave IV included modules on labor market activities, health and crime behavior and characteristics of the neighborhood where the individual resides.

By definition, a study of the long-term implications of school composition must examine school composition in an earlier period than the present. School composition in the U.S. has undergone further change since the recruitment of the Add Health cohort. We discuss this and the potential implications of this study's findings for today's adolescents in the final section of the study.

\section{Measures}

The aim of the study is to provide a multidimensional characterization of peer composition effects by examining a broad set of social and educational outcomes first when students are in school (short-term effects) and then fourteen years later in adulthood (long-term effects). The independent variable of interest for the analysis, school cohort composition, is measured from the In-School survey of over 90,000. We calculate the percent of students in each grade of each school who report being foreign-born. Because the data come from a near-census of schools (versus a sample), measurement error is minimized.

Measures of short-term outcomes also come from the In-School survey, which collected information on student's socio-demographic characteristics, family background, health status, risk behaviors, academic achievement, mental health, and school factors. To achieve a multidimensional characterization while also reducing the number of statistical tests and improving measurement, we follow Kling et al. (2007) (among others) by grouping a large number of outcome measures into a set of four domains: academic effort, social acceptance, 
health risk behaviors, and mental health. ${ }^{2}$ For each domain, we conduct principal component analysis (PCA) on the contributing survey measures and extract the first component to be used as the outcome measure. The PCA combines both dichotomous and continuous measures and allows individual measures to be negatively weighted to address reverse coding. Higher values on the resulting components indicate, respectively, greater academic effort, greater social acceptance, more engagement in health risk behaviors, and better mental health. PCA weights for the underlying measures are provided in supplementary materials. We complement analysis of these domains with a measure of language skills, captured with the PVT score taken from wave I of the In-Home survey.

The analysis of adult outcomes draws from the Wave IV In-Home survey. Akin to the analysis of adolescent outcomes, we group a rich array of individual measures into four domains that theoretically follow from the constructs measured in adolescence: health risk behavior, mental health, and residential economic status. ${ }^{3}$ We construct the residential economic status measure with information about poverty, employment, and average labor income values in the census track in which respondents live in Wave IV. To do this, we use geocodes with the restricted Add Health data to merge on track-level information from the American Community Survey. We also examine effects of peers on a PVT test score administered in Wave III and on

\footnotetext{
2 The composite dependent variables for the adolescent analysis were constructed through extracting the first principal component of survey variables from Wave I In-School survey grouped as follows: academic effort: Try to do homework well, Time spent watching TV on school day, Skipped school during last 12 months, Trouble getting homework done, Trouble getting along with teacher; social acceptance: Student responses to questions indicating that they: Feel close to peers, Feel part of school, Feel that students at school are prejudiced, Are happy to be at this school, Feel socially accepted; health risk behavior: Smoked cigarettes last 12 months, Drank alcohol last 12 months, Got drunk last month, Raced on bike or car last 12 months, In danger due to a dare last 12 month; mental health: Felt depressed last month, Trouble relaxing last month, Moody last month, Cried a lot last month. Descriptive statistics and component weights are provided in the Supplementary Online material, Appendix Tables A2 and A3.

${ }^{3}$ The composite dependent variables for the long-term analysis were constructed through extracting the first principal component of the underlying variables from the Wave IV In-Home survey grouped as follows: health risk behavior: Days smoked last month, Days drunk last year, Days smoked marijuana last month, Has used hard drugs; mental health: How often feel isolated, Not in control of life, Confident to handle problems, Things go respondent's way, Overwhelmed with difficulties, Bothered by things last week, Blues last week, Feel as good as others last week, Trouble concentrating last week, Depressed last week, Tired last week, Happy last week, Enjoyed life last week, Sad last week, Feel disliked last week, Feel not respected last week; residential economic status: Unemployment rate, Male labor force participation rate, Log income per capita, Proportion persons in poverty, Proportion of housing vacant, Log median house value, Total adult arrests, Total juvenile arrests. Descriptive statistics and component weights are provided in the Supplementary Online material, Appendix Tables A2 and A3.
} 
Wave IV years of education and earnings where the logarithm of one plus earnings is used to address skewness in the earnings data and avoid dropping observations with zero earnings.

\section{Samples}

Analysis of most of the short-term outcomes uses an analytical sample of 84,671 students from 141 schools, in grades 7 through 12 . Of the 90,118 students originally surveyed, 6.6 percent are missing data on sex, age, or foreign-born status information and must be excluded. The PVT score was collected for the subset of students sampled for the In-Home survey, and as a result is estimated on a sample of approximately 13,800 students.

Analysis of long-term outcomes uses the In-Home sample followed through Wave IV. approximately $20 \%$ of 13,800 sampled individuals attrite from the Add Health data by Wave IV, resulting in an empirical sample of between 9,000 and 11,000 observations, depending on the outcome. Attrition across survey waves risks selection bias in the estimates, particularly if attrition is correlated with the predictor of interest, the percent foreign-born by grade. We tested whether \% foreign-born by grade predicted missingness in the measures and attrition by Wave 4 (see Table A4, Supplementary Online Materials). We find little evidence that missing data or sample attrition is selective on grade composition. Our results show a small positive and not statistically significant relationship between peer exposure and remaining the sample for foreign born students (a 3 percentage point increase in exposure is associated with a 0.6 percentage point increase in the likelihood of being retained in the sample) and no association for native born students.

\section{Descriptive Statistics}

Roughly $10 \%$ of the sample reports being foreign-born. These students are distributed unevenly across schools and grades, creating wide variation in the share of foreign-born students by grade; this variable ranges from zero to $100 \%$. The clustering of immigrant students results in a large difference in average cohort composition for foreign-born students (25\% of grade-mates are foreign-born) versus US-born students (8\% of grade-mates are foreign-born). ${ }^{4}$

\footnotetext{
${ }^{4}$ Distributions shown in Figure A1 of the Online Supplement.
} 
Table 1 presents the mean, standard deviation, minimum and maximum of outcome and control variables. The table illustrates several differences between the US-born and foreign-born students in background characteristics, as well as academic, behavioral and health outcomes. Foreign-born students are advantaged in some domains, but disadvantaged in others compared to their US-born counterparts. Foreign-born students express social acceptance that is about 5\% of a standard deviation lower and mental health that is $11.5 \%$ of a standard deviation better than US-born students, as captured by the principal component scales. However, foreign-born students are also $16 \%$ of a standard deviation lower in pursuing risky health behaviors and $6 \%$ of a standard deviation lower in their academic effort. In terms of the family background variables, foreign-born students have parents that are less likely to be in professional occupations, but have a similar likelihood of attending college relative to parents of their US-born peers.

\section{Balancing Tests}

The study's identification assumes that though families might systematically select into schools, they do not sort into schools based on their child's cohort in school, which is primarily a function of the school and the child's birth date. We conduct a battery of balancing tests that examine the extent to which the deviations from the school average of cohort composition are correlated with student demographic and background characteristics. If the school fixed effects capture systematic selection on observed family and student characteristics, then we expect to find little or no correlation between student attributes and cohort deviations. In the peer effects literature, it is common to validate this assumption by testing whether families sort into schools based on their child's cohort using observable attributes like student demographics or family background. The logic behind these tests is that if students have not systematically sorted based on key observables like race or parental income then they are unlikely to have sorted based on the factors that were not recorded in the survey, which presumably were not recorded often because they were less central than the observables (Altonji, Elder, and Taber 2005).

Table 2 presents the results of these balancing tests, in which the dependent variables are the family and student characteristics. These variables are regressed on the grade share foreignborn using the same specification as shown in equation (2). Only two of the 28 balancing test estimates are significant at the 5\% level, which represents a set of results that could easily have arisen due to type 1 error. However, both of these failures are on variables related to race and 
ethnicity and some of the estimates on race and ethnicity variables are sizable in magnitude whether statistically significant or not. Given the nature of immigration within the U.S., it is unsurprising that we cannot easily separate foreign-born status from race and ethnicity, and so we repeat the balancing conditional on the race and ethnicity variables. Those tests are supportive of our identification strategy as long as the models condition on both whether the individual is foreign born and their racial and ethnic background. ${ }^{5}$

\section{RESULTS}

\section{Effects on Outcomes in Adolescence}

The results of Eq. 1 estimates are shown in Table 3. Panel 1 presents the estimates with no additional controls, panel 2 includes controls for race and ethnicity, and panel 3 includes controls for all balancing test variables. With one exception, the estimates are qualitatively similar across the panels. The effects of the share of foreign-born students on the outcomes of US-born students can be approximately detected from the zero-order term (\% peers foreign-born). We only find evidence of peer effects of foreign-born students on their US-born counterparts for mental health, and those effects erode substantially as we add controls. We do not find any statistically significant effects for the other domains considered: academic effort, social acceptance, or risk-taking behavior. We note, however, that the estimates on mental health and academic effort are both negative but imprecisely estimated. We then turn to the effect on Picture-Vocabulary Test (PVT) scores, collected in the In-Home survey. The PVT tests vocabulary of Standard American English and is meant as an estimate of verbal and scholastic ability. We similarly find little evidence that attending school with a larger share of foreign-born students reduces the test scores of US-born students. We confirm these findings with identical analysis limited to the US-born sample (not reported).

When we consider the effects of grade composition on foreign-born students relative to natives, we observe a different pattern. We find evidence for differences in peer effects for foreign-born students for all of the in-school outcomes tested. Compared to the native-born students, we see that as the share of foreign-born peers increases in the cohort, the foreign-born

\footnotetext{
${ }^{5}$ Identification also requires that sufficient across-cohort variation in the share foreign-born remains after controlling for school fixed effects. Appendix Table A5 shows that approximately 3.5 percent of the variation in share foreign-born survives conditioning on school.
} 
students feel more socially accepted, have better mental health engage in less risky behavior and exhibit greater academic effort, relative to the native born. ${ }^{6}$ The point estimate for peer effects of foreign-born students are the sum of the zero-order estimate and the interaction. For three outcomes in panel 3, these sums are sizable and in the direction described above. Foreign-born students report feelings of social acceptance that are almost 40 percent of a standard deviation larger $((0.266+0.077) / 0.86)$ with a 100 percentage point increase in the share of the grade that is also foreign-born. A 19.9-percentage point increase in the share of foreign-born peers, i.e. one standard deviation in foreign-born share for the foreign born population, is associated with an $8 \%$ of a standard deviation increase in the social acceptance scale. Immigrant students' engagement in risky behavior is reduced by 7\% of a standard deviation (19.9*(0.212 0.545)/0.92). For mental health and academic effort, we are unable to distinguish between situations where there are positive peer effects for foreign-born students or where there are negative (but noisily estimated) peer effects for native-born students and those effects do not exist for foreign-born students. All of the zero order estimates for foreign-born students are shown in Appendix Table A6. The estimates are noisier than the interacted effects; specifically, group-specific effects are less precisely estimated than is the difference between effects on foreign-born relative to native-born students.

When we turn to the effect on vocabulary scores, we see that the PVT score of foreignborn students suffer with increased exposure to foreign-born peers, relative to their native-born counterparts. This result is precisely estimated, and the magnitude of this effect is striking. The standard deviation of the standardized PVT score is 1.24; therefore a 19.9-percentage point increase of the share of foreign-born induces $15 \%$ of a standard deviation decrease in the PVT score.

As discussed above, Table 3 presents results first without controls, then with controls for race and ethnicity and finally with all balancing test controls. If the assumption of the study design holds, we would not expect the control measures to play much of a role in the analysis. If the school and grade fixed effects have absorbed the processes that sort families into different

${ }^{6}$ Of course, these measures can be constructed in alternate ways. To consider the robustness of the findings, we tested regression specifications predicting individual component variables one-by-one. Out of twenty-three outcome variables considered, we find statistically meaningful peer effects on the interaction term with foreign-born students in all but seven cases. These effects operate in the direction signaled in Table 3 - they increase social inclusion and decrease harmful behavior. 
schools, we would not expect the coefficients estimated on cohort composition to change much with the inclusion of additional controls. As discussed alongside the balancing test results, it is difficult to separate foreign-born status from race and ethnicity, and the coefficients exhibit some parameter instability between panels 1 and 2 when we introduce measures of race. Focusing on the interaction between foreign-born and the share foreign born: the parameters are quite stable as the additional controls are added, i.e. between panels 2 and 3. We further test the study's identifying assumption with an analysis of effect size changes to covariate inclusion, drawing from Oster (2015) who compares parameter changes to changes in R-squared as the controls are added. These tests indicate that the study results are robust to all but extreme forms of selection on unobserved measures. ${ }^{7}$

We then investigate whether these effects endure as the adolescents age into adulthood. For this purpose, we take advantage of the panel nature of the Add Health and examine outcomes found in waves III and IV of the In-Home survey. Standardized PVT scores were collected in Wave III, when the respondents were 18 to 24 years old. We use information on labor market, health, social and behavioral outcomes found in Wave IV, completed when the respondents were between 24 and 30 years old. Importantly, the Wave III and IV surveys follow (by design) a sub-set of the In-School Survey respondents—approximately 15,000 of the original 90,000_this survey feature has implications for our power to detect long-term effects in relation to the shortterm effects we have outlined above.

The results of this analysis are found in Table 4. We find effects for health behavior and PVT score in early adulthood that operate in the same direction as the effects in adolescence but are attenuated in magnitude. However, we find no effects on either earnings or residential environment. We find small, negative effects of the share of immigrant students on years of education attained for immigrant relative to native-born students. Turning to the zero-order effects explicitly: for the PVT score, a one standard deviation difference in exposure to foreignborn peers lowers foreign-born student scores by about 6.5 percent of a standard deviation

\footnotetext{
7 These tests are described in detail in the Supplementary Online Material. The results are shown in Appendix Table A7.
} 
$(19.9 *(0.074-0.444) / 1.14)$, and the same change reduces years of education by 0.05 years. ${ }^{8,9}$ Note that the estimates in Table 4 exhibit more parameter stability, likely due to the small sample size. These estimates still pass the Oster tests for outcomes with statistically significant peer effect estimates, again for all but extreme forms of selection.

\section{Heterogeneous Peer Effects in Adolescence}

To this point, the study does not distinguish among foreign-born adolescents in terms of ethnic origin or race. The U.S. foreign-born population is heterogeneous in many dimensions, including ethnicity and associated country of origin. Research on peer networks in adolescence point to the importance of race and ethnicity in the process of friendship formation (Moody 2001; Currarini, Jackson, and Pin 2010). As a result, we might expect that the effects of attending school with foreign-born peers matters more if these peers share ethnic origin or race. Alternatively, they may matter less if small variation in peers is more important when there are few foreign-born peers available.

For this purpose, we construct a variable that indicates the proportion of the foreign-born peers at the school level that share the same racial/ethnic group as a given student, whether or not the student is foreign born. We first construct this variable based on broad, pan-ethnic indicators for race and ethnicity. For students identifying as Asian and Hispanic in Add Health, it is possible to then create a second variable indicating the proportion of foreign-born peers that share the same country of origin. The means of these variables are shown in Table 5 panel 1 (race and ethnicity) and panel 2 (country of origin) separately by student foreign-born status and by whether the school has an above- or below-median share of foreign-born students. We then interact each of these variables with the share of foreign-born peers, the foreign-born indicator

\footnotetext{
${ }^{8}$ We re-estimate these models without school fixed effects in order to identify the conditional correlation between peer attributes and student outcomes. Failure to control for school fixed effects leads to evidence that might suggest larger effects on native born students, such as less health risk behavior and higher earnings, and more long-term effects on foreign-born students, such as better mental health and worse residential economic status. See Appendix Table A8.

${ }^{9}$ We can repeat these analyses using students who are either first or second-generation immigrants and measures of the share of first or second generation immigrants in the student's cohort, i.e. either foreign-born or have at least one foreign-born parent. The results in Appendix Tables A9 and A10 are similar, but the effect sizes are smaller, than the results in Tables 3 and 4.
} 
and their interaction. In light of the previous findings and the sample needed to support this analysis, we focus the tests on the short-run outcomes.

The results for the interaction between foreign-born peers and foreign-born status are presented in Table 6 . The first panel repeats the short-run results from the final panel in Table 3 for reference. The second panel presents the results based on share same race or ethnicity, and the third panel presents the results based on shared country of origin. The results are similar for both share same race or ethnicity and for share same country of origin. Specifically, in the third row (\% peers foreign born interacted with student foreign born) in both panels 2 and 3, the peer effects are larger and in the same direction as before, while the interaction of this variable with percent-shared is in the opposite direction and sizable. Most of the effects of more foreign-born students on foreign-born students are concentrated among foreign-born students who attend a school with more diverse foreign-born populations - or, where fewer of their foreign-born classmates share their race, ethnicity or country of origin.

This finding suggests that having additional foreign-born classmates is more meaningful when foreign-born students have fewer peers of similar origin from which to select friends or acquaintances. ${ }^{10}$ As discussed above, one should not interpret these results as implying that there are no peer effects among the foreign-born when foreign-born peers are similar on race, ethnicity or country of origin. Rather, at a sufficiently high level of similarity, schools may present sufficient homophilous friendship opportunities such that students who are disposed to form these friendships will experience the same peer effects even if the number of foreign-born peers increases.

If the role of similarity is driven by homophily in friendships, one might also expect that peer effects for foreign-born share would be non-linear where the importance of increasing the share of additional foreign-born students is smaller at schools with higher shares of foreign-born students. Similarly, both the presence of second-generation immigrant students and students who do not speak English at home may increase the opportunities for friendships that are isolated from the broad population of non-immigrant students in the school. We create dummy variables for whether each school has an above median share of foreign-born students, second-generation

\footnotetext{
${ }^{10}$ Estimates are noisy and effects on long-term outcomes are difficult to detect given the smaller samples. See Appendix Table A11.
} 
immigrant students and students who do not speak English at home, and we estimate models that interact the foreign-born peer variables with these school attributes comparing the estimates on the interaction of student foreign-born and share foreign born to a triple interaction of those two variables with the school dummy variable, as shown in Eq. 4. For all three school attributes and all outcomes, the triple interaction coefficient is opposite in sign and approximately the same magnitude as the estimate on the interaction of student foreign-born and share foreign born. The effect of additional foreign-born students on foreign-born students in the same cohort is near zero when schools have above median share foreign-born, share second generation immigrants and share not speaking English at home, a very similar pattern to the results in Table 6 based on the racial, ethnic or country of origin similarity. These results are shown in Appendix Table A12.

\section{DISCUSSION}

Changes in regional mobility have reshaped the residential settlement patterns of immigrant families. An important, widely-recognized implication of this trend is the accompanying compositional shift in peers with whom children and adolescents encounter at home and at school. Being educated with a larger (or smaller) share of foreign-born students has potential implications for a number of developmental markers, for both foreign-born and US-born students.

We estimate the effect of presence of immigrant students in schools. We build on previous work — that almost exclusively leverages point-in-time administrative data—to study peer composition effects on a broad array of outcomes, including human capital, mental health, social acceptance, and health behavior. The data also allows us to follow individuals longitudinally and investigate the long-term consequences of peer composition in adolescence. We consider whether these effects differ for students who share ethnic identification with a larger share of the foreign-born students in their schools.

We find that the presence of immigrant peers has significant positive effects on other immigrants in the short term. Schooling with a larger share of foreign-born students increases academic effort and feelings of social inclusion, improves mental health and decreases risky behavior. We also find significant negative effects on the standardized PVT score of the foreignborn students, providing a more complicated picture of the impact of more and less segregated schooling experiences for foreign-born students. These effects are smaller when a foreign-born 
student shares the race, ethnicity or country of origin with the other foreign-born students in the school. These findings appear consistent with threshold effects where the effects of additional foreign-born students are most important when foreign-born students have smaller numbers of similar peers available. We find little evidence that presence of foreign-born peers negatively affects their US-born classmates.

When we follow individuals longitudinally, we find that the negative effects on the PVT score persist. This effect is accompanied by small, negative effects on completed schooling by early adulthood. By contrast, we find no evidence of an enduring effect of peer composition on adult earnings. Although education and earnings are correlated, the effects on language and schooling appear to be small enough that they are not translating into a decline labor market returns. Alternatively, these effects may be off-set by advantages arising from having a better foreign-born job network.

We also observe that the short-term positive results on health behavior fade by the time the respondents are 24 to 30 years old. The diminishment of these effects warrants attention in future research. The loss of these health benefits by adulthood is consistent with research that demonstrates an association between time spent in the U.S. and worsening health (Antecol and Bedard 2006; Lopez-Gonzalez et al. 2005; Hamilton, Palermo, and Green 2015). It is also consistent with research finding that networks in high school may be less protective when firstgeneration students leave home and navigate new institutions_college, service, employment, and so forth (e.g., Gonzales 2016).

The results shown here differ in significant ways fro other research using quasiexperimental design to peer effects. Most studies in European populations have examined testing outcomes. Our results demonstrate that an exclusive focus on testing in the European research may be missing other domains in which immigrant peer effects are beneficial. Further, while we find small negative effects of attending school with a larger share of foreign-born students on vocabulary testing, these effects are limited to foreign-born students. The absence of effects on native-born students for testing outcomes is consistent with Conger's (2015) study of Florida students and Schwartz and Stiefel's (2011) research on NYC students.

The Add Health data allows us to examine a rich array of outcomes. However, the study does not support analysis of English-language learning (ELL) status among students. ELL status is a theoretically important source of heterogeneity in peer effects research, though one that has 
not borne out as empirically significant to peer outcomes in the U.S. (e.g., Conger 2015). The Add Health In-School survey does not ask about gradations of language skill. The survey meta data record the language in which the survey is taken, but an indicator of responding in a language other than English represents a tiny share of respondents $(<1 \%)$. Tests using this data in triple-interactions were uninformative. ${ }^{11}$

Interpreting the results of this study requires attention to a few points. To improve measurement and to reduce the number of statistical tests-and the attendant risk of showing only a subset of findings - we use a data reduction exercise that incorporates a large set of indicators from the rich Add Health data. We chose these items based on theoretical grounds (versus data exploration) and generate outcome measures using the first principal component of each of these variable sets (see for example, Kling et al. 2007).

It is also important to stress that the identification strategy used in the present study focuses on the causal effect of attending school in a cohort with a larger or smaller share of immigrant peers. It is of course possible that shifts in immigrant peers generate change that is not grade specific, but school-specific. Consider for example, a school that hires a new principal or additional teaching aids, or tailors the curriculum in response to a rising share of immigrant families in a community. If this type of response has a positive effect on all of the foreign-born students in a school, the cross-cohort, within-school identification will sweep out this variation and underestimate the salutary effects on immigrant students of having the share of immigrants in the school increase (i.e., increases beyond that reflected in the grade alone). Similarly, there is some evidence that parents respond to the overall school immigrant composition by moving to other school districts or by moving children to private schools (Cascio and Lewis 2012). The differential selection of students into the school in response to the cohort composition might affect the overall learning environment, but this study cannot speak to the effect of this selection mechanism. Finally, immigration in the local labor market might affect student's outcomes through demand for particular skills in the labor market, or through competition for college admissions (e.g., Burstein et al. 2017). Such overall impacts of the immigrants in a given labor or

\footnotetext{
11 The survey does collect information in the In-Home survey about languages spoken at home, and we find no effects of higher foreign-born share in schools with above median share of students not speaking English at home. Whether this represents ELL status for students is ambiguous. It may also represent multilingualism.
} 
college market operate above and beyond the impacts that we uncover in this paper and deserve a dedicated study of its own.

The identification used here is useful in considering a broad class of policies that likely have consequences for changes in peer interactions between US-born and foreign-born students. For example, many policies around school choice measures and charter schools may create modest changes in the composition of students (Bifulco, Ladd and Ross 2009). Our results suggest that these policies could indeed differentially affect foreign-born and native-born students in the domains described above. Busing policies are another example that might change the average level of contact between foreign-born and native-born students. Policies that shift the likelihood of contact with foreign-born students could have similar impacts to those described here. It is worth noting that qualitative research on busing policies suggest that lower-income students are highly racialized and that the effects of intergroup interaction are heavily shaped by students' gender (Ispa-Landa 2012). Future work using the type of the design explored here would benefit from explicit attention to how peer effects differ by gender.

More broadly, the results suggest opportunities to leverage the positive effects of schoolbased ethnic enclaves in terms of social cohesion and health risk behaviors and at the same time deploy additional resources to further enhance English proficiency in first generation students. And for immigrant students who are educated in places with larger shares of US-born peers, ongoing research on mechanisms of support—particularly in "New Destination” regions—is warranted (e.g., Perreira et al. 2015; Silver 2015). By definition, our research on the longer-term effects of school composition are focused on the outcomes of schools in the 1990s. Since then, immigration patterns and internal migration patterns have continued to change. Movement into new destination regions increased substantially in the 1990s - the number of immigrants increased at 14 percent per year between 1990-2000 (Terrazas 2011). The Add Health cohort was recruited in 1997 and migration has continued to change the composition of southern and eastern regions of the country since then. We use data from the 1990 and 2000 Census and the 2015-2017 ACS to shed some light on this (Online Appendix A15). The evidence indicates that foreign-born adolescents are less likely to drop out of school and less likely to be employed now than in the 1990s; they also live in smaller, better educated families. Alongside these changes, the results here provide little evidence that a rising share of foreign-born students in adolescents' 
classrooms in new destination regions will negatively affect US-born students’ wellbeing, undermining the evidentiary support for political rhetoric to this effect. 


\section{REFERENCES}

Altonji, Joseph G., Todd E. Elder, and Christopher R. Taber. "Selection on observed and unobserved variables: Assessing the effectiveness of Catholic schools." Journal of Political Economy 113.1 (2005): 151-184.

Ackert, E. (2018). Segregation paradox? School racial/ethnic and socioeconomic composition and racial/ethnic differences in engagement. Social Science Research, 70, 144-162.

Angrist, Joshua and Kevin Lang. Does school integration generate peer effects? Evidence from Boston's Metco program. American Economic Review, 94 (5) (2004), pp. 1613-1634.

Antecol, Heather, and Kelly Bedard. (2006). Unhealthy Assimilation: Why Do Immigrants Converge to American Health Status Levels? Demography 43(2):337-60.

Ballatore, Rosario , Margherita Fort, Andrea Ichino. The Tower of Babel in the Classroom? Immigrants and Natives in Italian Schools (2013) (Mimeo)

Bifulco, Robert, Jason M. Fletcher, and Stephen L. Ross. "The effect of classmate characteristics on post-secondary outcomes: Evidence from the Add Health." American Economic Journal: Economic Policy 3, no. 1 (2011): 25-53.

Bifulco, Robert, Helen Ladd, and Stephen L. Ross. (2009). "Public school choice and integration: Evidence from Durham, NC." Social Science Research, 38, 78-85.

Billings, Stephen B., David J. Deming, and Stephen L. Ross. In Press. Partners in crime: Schools, neighborhoods and the formation of criminal networks. American Economic Journal: Applied Economics.

Bleakley, H., \& Chin, A. (2004). Language skills and earnings: Evidence from childhood immigrants. Review of Economics and statistics, 86(2), 481-496.

Burke, Mary A., and Tim R. Sass. (2013) Classroom peer effects and student achievement. Journal of Labor Economics 31, no. 1 (2013): 51-82.

Burstein, A., Hanson, G., Tian, L., \& Vogel, J. (2017). Tradability and the Labor-Market Impact of Immigration: Theory and Evidence from the US (No. w23330). National Bureau of Economic Research.

Camarota, S., Griffith, B., \& Zeigler, K. (2017). Mapping the Impact of Immigration on Public Schools. Center for Immigration Studies.

Cascio, Elizabeth U., and Ethan G. Lewis. 2012. "Cracks in the Melting Pot: Immigration, School Choice, and Segregation." American Economic Journal: Economic Policy, 4(3): 91117.

Chachashvili-Bolotin, S., Lissitsa, S., Shavit, Y. and Ayalon, H. (2016), The Short Term Effects of Immigrant Students on the Educational Achievements of Native-Born Students. International Migration, 54: 150-161.

Conger, D. (2015), Foreign-born Peers and Academic Performance. Demography (2015) 52: 569 Crosnoe, R., \& Lopez-Gonzalez, L. (2005). Immigration from Mexico, school composition, and adolescent functioning. Sociological Perspectives, 48(1), 1-24. 
Currarini, S., Jackson, M. O., \& Pin, P. (2010). Identifying the roles of race-based choice and chance in high school friendship network formation. Proceedings of the National Academy of Sciences, 107(11), 4857-4861.

Diette, Timothy M., and Ruth Uwaifo Oyelere. "Gender and Race Heterogeneity: The Impact of Students with Limited English on Native Students' Performance." The American Economic Review 104, no. 5 (2014): 412-417.

Duncan, G. J., Boisjoly, J., Kremer, M., Levy, D. M., \& Eccles, J. (2005). Peer effects in drug use and sex among college students. Journal of abnormal child psychology, 33(3), 375-385.

Eren, Ozkan. "Differential Peer Effects, Student Achievement, and Student Absenteeism: Evidence From a Large-Scale Randomized Experiment." Demography 54, no. 2 (2017): 745773.

Figlio, D. N., \& Özek, U. (2017). Unwelcome Guests? The Effects of Refugees on the Educational Outcomes of Incumbent Students (No. w23661). National Bureau of Economic Research.

Fletcher, J. M. (2010). Social interactions and smoking: Evidence using multiple student cohorts, instrumental variables, and school fixed effects. Health Economics, 19(4), 466-484.

Fletcher, J. M. (2014). The effects of childhood ADHD on adult labor market outcomes." Health Economics 23(2): 159-181.

Gamoran, A., Collares, A. C., \& Barfels, S. (2016). Does racial isolation in school lead to longterm disadvantages? labor market consequences of high school racial composition. American Journal of Sociology, 121(4), 1116-1167.

Gándara, P., \& Hopkins, M. (2010). English learners and restrictive language policies. New York, Columbia University, Teachers College.

Gándara, P., \& Rumberger, R. W. (2009). Immigration, language, and education: How does language policy structure opportunity. Teachers College Record, 111(3), 750-782.

Gaviria, A., \& Raphael, S. (2001). School-based peer effects and juvenile behavior. Review of Economics and Statistics, 83(2), 257-268.

Geay, Charlotte, Sandra McNally, and Shqiponja Telhaj. "Non-native Speakers of English in the Classroom: What Are the Effects on Pupil Performance?." The Economic Journal 123, no. 570 (2013): F281-F307.

Goldsmith, P. A. (2003). All segregation is not equal: The impact of Latino and Black school composition. Sociological Perspectives, 46(1), 83-105.

Gonzales, R. G. (2016). Lives in limbo: Undocumented and coming of age in America. University of California Press.

Gould, Eric D., Victor Lavy, M. Daniele Paserman. Does immigration affect the long-term educational outcomes of natives? Quasi-experimental evidence. The Economic Journal, 119 (540) (2009), pp. 1243-1269

Haas, S. A., \& Fosse, N. E. (2008). Health and the educational attainment of adolescents: Evidence from the NLSY97. Journal of Health and Social Behavior, 49(2), 178-192. 
Hagelskamp, C., Suárez-Orozco, C., \& Hughes, D. (2010). Migrating to opportunities: How family migration motivations shape academic trajectories among newcomer immigrant youth. Journal of Social Issues, 66(4), 717-739.

Hainmueller, J., \& Hopkins, D. J. (2014). Public attitudes toward immigration. Annual Review of Political Science, 17.

Hamilton, Tod, Tia Palermo, Tiffany L. Green. (2015). Health Assimilation among Hispanic Immigrants in the United States: The Impact of Ignoring Arrival-cohort Effects. Journal of Health and Social Behavior 56(4):460-477.

Hanushek, Eric A., John F. Kain, Jacob M. Markman, and Steven G. Rivkin. "Does peer ability affect student achievement?." Journal of applied econometrics 18, no. 5 (2003): 527-544.

Hardoy, I., Mastekaasa, A., \& Schøne, P. (2018). Immigrant concentration and student outcomes in upper secondary schools: Norwegian evidence. European Societies, 20(2), 301-321.

Hardoy, I., \& Schøne, P. (2013). Does the Clustering of Immigrant Peers Affect the School Performance of Natives? Journal of Human Capital, 7(1), 1-25.

Harris, K. M. (1999). The health status and risk behaviors of adolescents in immigrant families. Children of immigrants: Health, adjustment, and public assistance, 286-347.

Hermansen, A. S., \& Birkelund, G. E. (2015). The impact of immigrant classmates on educational outcomes. Social Forces, 94(2), 615-646.

Hoxby, Caroline M. (2000). Peer effects in the classroom: learning from gender and race variation. Working Paper No. 7867, National Bureau of Economic Research (NBER)

Ispa-Landa, S. (2013). Gender, race, and justifications for group exclusion: Urban Black students bussed to affluent suburban schools. Sociology of Education, 86(3), 218-233.

Jensen, Peter, and Astrid Würtz Rasmussen. (2011). The effect of immigrant concentration in schools on native and immigrant children's reading and math skills." Economics of Education Review 30, no. 6: 1503-1515.

Kao, G. (2001). Race and ethnic differences in peer influences on educational achievement. Problem of the century: Racial stratification in the United States. p. 437-460.

Kling, Jeffrey R., Jeffrey B. Liebman, and Lawrence F. Katz. "Experimental analysis of neighborhood effects." Econometrica 75, no. 1 (2007): 83-119.

Kremer, M., \& Levy, D. (2008). Peer effects and alcohol use among college students. Journal of Economic perspectives, 22(3), 189-206.

Lavy, Victor, and Analia Schlosser. (2011). Mechanisms and impacts of gender peer effects at school. American Economic Journal: Applied Economics 3, no. 2: 1-33.

Lopez-Gonzalez, Lorena, Veronica C. Aravena, and Robert A. Hummer. (2005). Immigrant Acculturation, Gender and Health Behavior: A Research Note. Social Forces 84(1):577-89.

Manski, C. Identification of Endogenous Social Effects: The Reflection Problem. Review of Economic Studies 1993; 60 (3): 531-542.

Terrazas, A. (2011). Immigrants in new destination regions. Migration Policy Institute.

Moody, J. (2001). Race, school integration, and friendship segregation in America. American journal of Sociology, 107(3), 679-716. 
Ohinata, Asako, and Jan C. Van Ours. "How immigrant children affect the academic achievement of native Dutch children." The Economic Journal 123, no. 570 (2013): F308F331

Ohinata, Asako, and Jan C. Van Ours. "Quantile Peer Effects of Immigrant Children at Primary Schools." Labour 30, no. 2 (2016): 135-157.

Oster, Emily. (2014). "Unobservable selection and coefficient stability: Theory and evidence." University of Chicago Booth School of Business Working Paper.

Peguero, A. A., Ovink, S. M., \& Li, Y. L. (2016). Social bonding to school and educational inequality: Race/ethnicity, dropping out, and the significance of place. Sociological Perspectives, 59(2), 317-344.

Portes, A., \& Rumbaut, R. G. (2001). Legacies: the story of the immigrant second generation. Univ of California Press.

Portes, A., \& Zhou, M. (1993). Segmented assimilation and its variants. Annals of the American Academy of Political and Social Science, 530, 74-96.

Potochnick, S. (2014). The academic adaptation of children of immigrants in new and established settlement states: The role of family, schools, and neighborhoods. Population Research and Policy Review, 33(3), 335-364.

Ream, R. K. (2005). Toward understanding how social capital mediates the impact of mobility on Mexican American achievement. Social forces, 84(1), 201-224.

Ream, R. K., \& Rumberger, R. W. (2008). Student engagement, peer social capital, and school dropout among Mexican American and non-Latino white students. Sociology of Education, 81(2), 109-139.

Reyes, M. R., Brackett, M. A., Rivers, S. E., White, M., \& Salovey, P. (2012). Classroom emotional climate, student engagement, and academic achievement. Journal of Educational Psychology, 104(3), 700.

Salerno, S., \& Reynolds, J. R. (2017). Latina/o Students in Majority White Schools: How School Ethnic Enclaves Link Ethnicity with Success. Sociology of Race and Ethnicity, 3(1), 113125.

Schneeweis, Nicole. Educational institutions and the integration of migrants. J. Popul. Econ., 24 (4) (2011), pp. 1281-1308.

Schwartz, A. E., \& Stiefel, L. (2011). Immigrants and inequality in public schools. Whither Opportunity (Duncan, Ed), Pp. 419-442.

Silver, A. M. (2015). Clubs of culture and capital: Immigrant and second-generation incorporation in a new destination school. Ethnic and Racial Studies, 38(5), 824-840.

Spees, L., Perreira, K. M., \& Fuligni, A. (2017). Family Matters: Promoting the Academic Adaptation of Latino Youth in New and Established Destination. Journal of family issues, 38(4), 457-479.

Stanton-Salazar, R. D. (2000). The development of coping strategies among urban Latino youth. Making invisible Latino adolescents visible: A critical approach to Latino diversity, 203-238. 
Stanton-Salazar, R. D., \& Dornbusch, S. M. (1995). Social capital and the reproduction of inequality: Information networks among Mexican-origin high school students. Sociology of Education, 116-135.

Suárez-Orozco, C., Suárez-Orozco, M., \& Todorova, I. (2008). Learning a new land: Immigrants students in American society. Cambridge, MA: Harvard University Press.

Tonello, Marco. "Peer effects of non-native students on natives' educational outcomes: mechanisms and evidence." Empirical Economics (2015): 1-32

Vigdor, J., \& Nechyba, T. (2007). Peer effects in North Carolina public schools. Schools and the equal opportunity problem, 73-101.

Wang, M. T., \& Holcombe, R. (2010). Adolescents' perceptions of school environment, engagement, and academic achievement in middle school. American educational research journal, 47(3), 633-662.

Weinberg, B. (2013). Group design with endogenous associations. Regional Science and Urban Economics 43, 411-21.

Winship C. \& Korenman S.D. (1999). Economic Success and the Evolution of Schooling and Mental Ability. In: Mayer SE, Petersen PE. Earning and Learning: How School Matters. The Brookings Institution Press.

Wodtke, G.T. and Parbst, M., 2017. Neighborhoods, schools, and academic achievement: a formal mediation analysis of contextual effects on reading and mathematics abilities. Demography, 54(5), pp.1653-1676.

Zhou, M. (1997). Segmented assimilation: Issues, controversies, and recent research on the new second generation. International Migration Review, 31(4), 975-1008. 
Table 1. Sample Means by Students’ Foreign-Born Status

\begin{tabular}{|c|c|c|c|c|c|}
\hline & $\begin{array}{l}\text { Min } \\
(1)\end{array}$ & $\begin{array}{c}\operatorname{Max} \\
(2)\end{array}$ & $\begin{array}{l}\text { US- } \\
\text { Born } \\
\text { (3) }\end{array}$ & $\begin{array}{c}\text { Foreign- } \\
\text { Born } \\
\text { (4) }\end{array}$ & $\begin{array}{c}\text { t-stat } \\
\text { of (3)-(4) }\end{array}$ \\
\hline \multicolumn{6}{|l|}{ Outcomes in Adolescence (wave 1) } \\
\hline Social Acceptance & -2.522 & 1.413 & 0.004 & -0.044 & 4.099 \\
\hline Mental Health & -2.769 & 1.046 & -0.012 & 0.103 & 10.400 \\
\hline Health Risk Behavior & -0.749 & 3.773 & 0.015 & -0.151 & 14.356 \\
\hline Academic Effort & -2.646 & 1.204 & 0.008 & -0.055 & 6.827 \\
\hline PVT Scores & -5.648 & 2.594 & 0.130 & -0.521 & 24.359 \\
\hline \multicolumn{6}{|l|}{ Outcomes in Young Adulthood (waves 3 \& 4) } \\
\hline Family Income & 0.000 & 13.732 & 9.500 & 9.672 & 1.852 \\
\hline Mental Health & -4.370 & 1.387 & -0.003 & 0.038 & 1.236 \\
\hline Health Risk Behavior & -0.585 & 2.805 & 0.016 & -0.206 & 8.901 \\
\hline PVT Scores & -5.353 & 1.376 & 0.080 & -0.254 & 10.146 \\
\hline Years of Schooling & 8.000 & 19.000 & 13.507 & 13.599 & 1.407 \\
\hline Residential Economic Status & -5.171 & 2.521 & -0.013 & 0.170 & 5.781 \\
\hline \multicolumn{6}{|l|}{ Individual and Family Measures } \\
\hline Student’s Age & 10 & 19 & 14.935 & 15.550 & 31.186 \\
\hline Student is Female & 0 & 1 & 0.501 & 0.494 & 1.197 \\
\hline \multicolumn{6}{|l|}{ Student Race/Ethnicity: } \\
\hline White & 0 & 1 & 0.650 & 0.256 & 71.908 \\
\hline Black & 0 & 1 & 0.201 & 0.083 & 26.195 \\
\hline Asian & 0 & 1 & 0.045 & 0.292 & 88.257 \\
\hline American-Indian & 0 & 1 & 0.057 & 0.028 & 11.223 \\
\hline Hispanic & 0 & 1 & 0.134 & 0.503 & 89.177 \\
\hline Mother College Graduate or Higher & 0 & 1 & 0.295 & 0.287 & 1.331 \\
\hline Father College Graduate or Higher & 0 & 1 & 0.343 & 0.353 & 1.529 \\
\hline Either Parent Works for Pay & 0 & 1 & 0.958 & 0.924 & 13.040 \\
\hline Either Parent in Professional Occupation & 0 & 1 & 0.410 & 0.293 & 18.996 \\
\hline Live with Both Parents & 0 & 1 & 0.731 & 0.712 & 3.762 \\
\hline Household Size & 1 & 6 & 4.267 & 4.609 & 25.133 \\
\hline \multicolumn{6}{|l|}{ Peer measure } \\
\hline \% Peers Foreign-Born & 0.000 & 1.000 & 0.079 & 0.252 & 132.332 \\
\hline
\end{tabular}

Source: Add Health.

Note. Minimum and maximum values presented in columns 1 and 2. Unweighted mean values presented in columns 3 and 4. Sample size varies for estimates that include the full school sample (wave 1 outcomes) and estimates that draw from the inhome sample followed into waves 3 \& 4. Sample sizes shown in Tables 3 and 4. 
Table 2. Balancing Tests

\% Peers Foreign-Born

Conditional on
(1) (2) Foreign-Born $\quad \begin{array}{r}+ \text { Race an } \\ \text { Ethnicity }\end{array}$

\section{$\underline{\times \text { Foreign-Born }}$}

(3)

(4)

(0.101)

$-0.094$

(0.096)

0.054

(0.051)

$0.137^{*}$

(0.058)

0.014

(0.044)

$-0.130$

(0.075)

$-0.047$

(0.078)

0.134

(0.094)

$-0.064$

(0.115)

$-0.051$

(0.037)

0.028

(0.067)

$-0.023$

(0.080)

0.190

(0.208)

0.111

(0.226)

0.125

(0.099)

(0.099)

Foreign-Born

(0.164)

0.027

(0.026)

$0.475^{*}$
+ Race and Ethnicity

0.247

(0.169)

0.014

(0.230)

$-0.154$

(0.081)

$-0.313$

(0.178)

0.019

(0.032)

$-0.035$

(0.044)

$-0.137$

(0.115)

0.056

0.051

0.132

(0.046)

(0.043)

0.042

0.028

$-0.068$

(0.111)

(0.068)

(0.072)

$-0.047$

(0.037)

0.020

0.009

(0.022)

$-0.041$

$-0.078$

(0.065)

(0.050)

(0.049)

$0.112^{*}$

0.077

(0.076)

(0.048)

(0.040)

$-0.318$

$-0.211$

0.171

(0.167)
(0.023)

Note. Each cell contains coefficients from separate regressions that include an indicator that the student is foreign-born, school fixed effects, and grade fixed effects. Columns 1 and 2 show estimates on percent foreign-born, and columns 3 and 4 show estimates on the interaction of percent foreign-born with the foreign-born dummy. All regression specifications in Columns 2 and 4 control for race/ethnicity dummies. Robust standard errors are clustered at the school level. All estimates based on wave 1 in-school sample.

${ }^{*} p<0.05$, ** $p<0.01$, *** $p<0.001$ 
Table 3. Peer Effects on Student's Short-Term Outcomes

\begin{tabular}{|c|c|c|c|c|c|}
\hline & $\begin{array}{c}\text { Social } \\
\text { Acceptance } \\
\text { (1) }\end{array}$ & $\begin{array}{c}\text { Mental } \\
\text { Health } \\
(2)\end{array}$ & $\begin{array}{c}\text { Health } \\
\text { Risk } \\
\text { Behavior } \\
\text { (3) }\end{array}$ & $\begin{array}{c}\text { Academic } \\
\text { Effort } \\
(4)\end{array}$ & $\begin{array}{c}\text { PVT } \\
\text { Scores } \\
(5)\end{array}$ \\
\hline \multicolumn{6}{|c|}{ Conditional on Foreign-Born } \\
\hline \% Peers Foreign-Born & 0.038 & $-0.379^{*}$ & 0.162 & -0.260 & 0.020 \\
\hline & $(0.204)$ & $(0.166)$ & $(0.316)$ & $(0.231)$ & $(0.352)$ \\
\hline $\begin{array}{l}\% \text { Peers Foreign-Born } \times \\
\text { Student Foreign-Born }\end{array}$ & $\begin{array}{c}0.309^{* * *} \\
(0.086)\end{array}$ & $\begin{array}{c}0.219^{*} \\
(0.091)\end{array}$ & $\begin{array}{l}-0.475^{+} \\
(0.260)\end{array}$ & $\begin{array}{l}0.199^{* *} \\
(0.075)\end{array}$ & $\begin{array}{c}-0.788^{* * *} \\
(0.224)\end{array}$ \\
\hline R-squared & 0.040 & 0.038 & 0.080 & 0.034 & 0.224 \\
\hline \multicolumn{6}{|c|}{ Also Conditional on Race and Ethnicity } \\
\hline \% Peers Foreign-Born & $\begin{array}{l}0.070 \\
(0.199)\end{array}$ & $\begin{array}{l}-0.368^{*} \\
(0.164)\end{array}$ & $\begin{array}{c}0.175 \\
(0.310)\end{array}$ & $\begin{array}{l}-0.215 \\
(0.224)\end{array}$ & $\begin{array}{c}0.226 \\
(0.352)\end{array}$ \\
\hline$\%$ Peers Foreign-Born $x$ & $0.264^{* *}$ & $0.231^{* *}$ & $-0.535^{*}$ & $0.149^{*}$ & $-0.992^{* * * *}$ \\
\hline Student Foreign-Born & $(0.087)$ & $(0.080)$ & $(0.209)$ & $(0.073)$ & $(0.252)$ \\
\hline R-squared & 0.044 & 0.044 & 0.091 & 0.035 & 0.261 \\
\hline \multicolumn{6}{|c|}{ Conditional on All Covariates } \\
\hline$\%$ Peers Foreign-Born & $\begin{array}{c}0.077 \\
(0.194)\end{array}$ & $\begin{array}{l}-0.258 \\
(0.168)\end{array}$ & $\begin{array}{c}0.212 \\
(0.289)\end{array}$ & $\begin{array}{l}-0.238 \\
(0.209)\end{array}$ & $\begin{array}{c}0.084 \\
(0.364)\end{array}$ \\
\hline$\%$ Peers Foreign-Born $\times$ & $0.266^{* *}$ & $0.236^{* *}$ & $-0.545^{*}$ & $0.156^{*}$ & $-1.030^{* * *}$ \\
\hline Student Foreign-Born & $(0.091)$ & $(0.087)$ & $(0.220)$ & $(0.076)$ & $(0.214)$ \\
\hline R-squared & 0.058 & 0.144 & 0.120 & 0.065 & 0.322 \\
\hline $\mathrm{N}$ & 73,482 & 78,239 & 78,546 & 78,065 & 14,082 \\
\hline
\end{tabular}

Note. Coefficient estimates from regressions predicting five outcome measures. Standard errors in parentheses. All specifications include grade and school fixed effects, as well as a control for foreign-born. The second panel presents estimates after adding controls for the race and ethnicity variables, and the third panel estimates after adding all controls listed in Table 2 above. The first four columns based on the wave 1 in-school sample. The final column results for PVT scores based on the wave 1 in-home sample.

$+p<0.10, * p<0.05, * * p<0.01,{ }^{* * *} p<0.001$ 
Table 4. Peer Effects on Student's Long-Term Outcomes

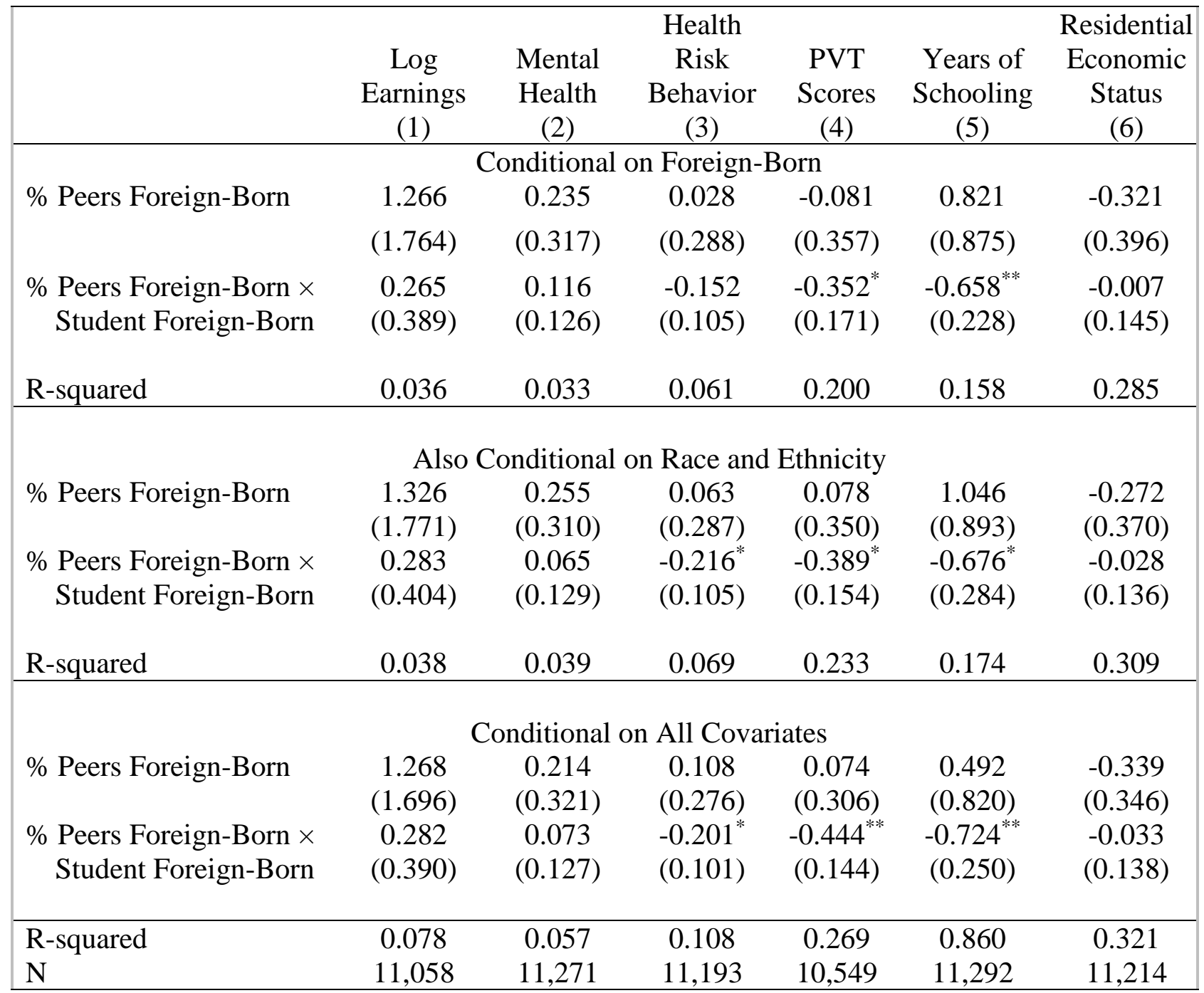

Note. Coefficient estimates from regressions predicting six outcome measures. Standard errors in parentheses. All specifications include grade and school fixed effects, as well as a control for foreign-born. The second panel presents estimates after adding controls for the race and ethnicity variables, and the third panel estimates after adding all controls listed in Table 2 above. All columns based on the wave 4 sample, except for the fourth column results for PVT score that are based on the wave 3 sample.

$+p<0.10, * p<0.05, * * p<0.01, * * * p<0.001$ 
Table 5. Mean of Percent School Shared Subgroup

\begin{tabular}{|c|c|c|c|c|}
\hline \multirow{3}{*}{ Student's Race/Ethnicity } & \multicolumn{4}{|c|}{ Shared Race and Ethnicity } \\
\hline & \multicolumn{2}{|c|}{ \% FB Below Median } & \multicolumn{2}{|c|}{ \% FB Above Median } \\
\hline & Native-Born & $\begin{array}{l}\text { Foreign- } \\
\text { Born }\end{array}$ & Native-Born & $\begin{array}{l}\text { Foreign- } \\
\text { Born }\end{array}$ \\
\hline White & 0.406 & 0.474 & 0.264 & 0.313 \\
\hline Black & 0.299 & 0.330 & 0.130 & 0.177 \\
\hline Hispanic & 0.095 & 0.170 & 0.249 & 0.349 \\
\hline Asian & 0.045 & 0.146 & 0.148 & 0.225 \\
\hline American Indian & 0.012 & 0.095 & 0.004 & 0.020 \\
\hline Others & 0.049 & 0.131 & 0.053 & 0.059 \\
\hline \multicolumn{5}{|c|}{ Shared Country of Origin for Hispanic and Asian Students } \\
\hline \multirow[t]{2}{*}{ Student’s Country of Origin } & \multicolumn{2}{|c|}{ \% FB Below Median } & \multicolumn{2}{|c|}{ \% FB Above Median } \\
\hline & Native-Born & $\begin{array}{c}\text { Foreign- } \\
\text { Born }\end{array}$ & Native-Born & $\begin{array}{c}\text { Foreign- } \\
\text { Born }\end{array}$ \\
\hline Hispanic-Mexican & 0.187 & 0.271 & 0.425 & 0.467 \\
\hline Hispanic-Chicano & 0.018 & 0.097 & 0.010 & 0.024 \\
\hline Hispanic-Cuban & 0.027 & 0.105 & 0.253 & 0.297 \\
\hline Hispanic-Puerto Rican & 0.058 & 0.106 & 0.063 & 0.066 \\
\hline Hispanic-Central / South American & 0.063 & 0.174 & 0.222 & 0.392 \\
\hline Hispanic-Others & 0.053 & 0.115 & 0.079 & 0.113 \\
\hline Hispanic-Multiple/Missing & 0.000 & 0.000 & 0.000 & 0.000 \\
\hline Asian-Chinese & 0.053 & 0.093 & 0.168 & 0.159 \\
\hline Asian-Filipino & 0.039 & 0.122 & 0.331 & 0.369 \\
\hline Asian-Japanese & 0.014 & 0.068 & 0.039 & 0.085 \\
\hline Asian-Asian Indian & 0.035 & 0.145 & 0.040 & 0.046 \\
\hline Asian-Korean & 0.057 & 0.125 & 0.189 & 0.336 \\
\hline Asian-Vietnamese & 0.118 & 0.236 & 0.087 & 0.138 \\
\hline Asian-Others & 0.056 & 0.167 & 0.039 & 0.078 \\
\hline Asian-Multiple/Missing & 0.000 & 0.000 & 0.000 & 0.000 \\
\hline
\end{tabular}

Note. This table presents the mean value of the school level fraction of foreign-born students who share the same race or ethnicity or in the case of Panel Two the same country of origin as the current student. Columns 1 and 3 present the means for native-born students, and columns 2 and 4 present the means for foreign-born students. The first two columns present means for schools that have a percent of students who are foreign born below the median, and the last two columns present the means for the school that have an above median percent foreign-born. 
Table 6. Role of Percent Foreign Born Same Subgroup on Student’s Short-Term Outcomes

\begin{tabular}{|c|c|c|c|c|c|}
\hline & $\begin{array}{c}\text { Social } \\
\text { Acceptance } \\
\text { (1) }\end{array}$ & $\begin{array}{c}\text { Mental } \\
\text { Health } \\
\text { (2) }\end{array}$ & $\begin{array}{c}\text { Health } \\
\text { Risk } \\
\text { Behavior } \\
\text { (3) }\end{array}$ & $\begin{array}{c}\text { Academic } \\
\text { Effort } \\
\text { (4) }\end{array}$ & $\begin{array}{c}\text { PVT } \\
\text { Scores } \\
(5)\end{array}$ \\
\hline \multicolumn{6}{|c|}{ Baseline Peer Effects } \\
\hline \% Peers Foreign-Born & 0.077 & -0.258 & 0.212 & -0.238 & 0.084 \\
\hline & $(0.194)$ & $(0.168)$ & $(0.289)$ & $(0.209)$ & $(0.364)$ \\
\hline $\begin{array}{l}\text { \% Peers Foreign-Born } \times \\
\text { \% School Shared Ethnicity }\end{array}$ & $\begin{array}{l}0.266^{* *} \\
(0.091)\end{array}$ & $\begin{array}{l}0.236^{* *} \\
(0.087)\end{array}$ & $\begin{array}{l}-0.545^{*} \\
(0.220)\end{array}$ & $\begin{array}{l}0.156^{*} \\
(0.076)\end{array}$ & $\begin{array}{l}-1.030^{* * *} \\
(0.214)\end{array}$ \\
\hline \multicolumn{6}{|c|}{ Peer Effects by Percent Shared Race and Ethnicity } \\
\hline \% Peers Foreign-Born & $\begin{array}{c}0.126 \\
(0.212)\end{array}$ & $\begin{array}{l}-0.211 \\
(0.175)\end{array}$ & $\begin{array}{c}0.194 \\
(0.308)\end{array}$ & $\begin{array}{l}-0.245 \\
(0.211)\end{array}$ & $\begin{array}{c}0.148 \\
(0.359)\end{array}$ \\
\hline $\begin{array}{l}\text { \% Peers Foreign-Born } \times \\
\text { \% School Shared Ethnicity }\end{array}$ & $\begin{array}{l}-0.096 \\
(0.169)\end{array}$ & $\begin{array}{l}-0.083 \\
(0.106)\end{array}$ & $\begin{array}{l}-0.034 \\
(0.141)\end{array}$ & $\begin{array}{c}0.044 \\
(0.106)\end{array}$ & $\begin{array}{l}-0.139 \\
(0.168)\end{array}$ \\
\hline$\%$ Peers Foreign-Born $\times$ & $0.469^{*}$ & $0.335^{+}$ & $-1.145^{* *}$ & 0.137 & $-1.960^{* * *}$ \\
\hline Student Foreign-Born & $(0.207)$ & (0.178) & $(0.402)$ & $(0.216)$ & $(0.422)$ \\
\hline$\%$ Peers Foreign-Born $\times$ & $-0.458^{+}$ & -0.254 & $1.206^{* *}$ & -0.025 & $1.279^{*}$ \\
\hline $\begin{array}{l}\text { Student Foreign-Born } \times \\
\text { \% School Shared Ethnicity }\end{array}$ & $(0.244)$ & $(0.191)$ & $(0.402)$ & $(0.263)$ & $(0.591)$ \\
\hline \multicolumn{6}{|c|}{ Peer Effects by Percent Shared Country of Origin for Hispanics and Asians } \\
\hline \% Peers Foreign-Born & $\begin{array}{c}0.023 \\
(0.195)\end{array}$ & $\begin{array}{l}-0.320^{+} \\
(0.170)\end{array}$ & $\begin{array}{c}0.213 \\
(0.307)\end{array}$ & $\begin{array}{l}-0.304 \\
(0.212)\end{array}$ & $\begin{array}{c}0.071 \\
(0.375)\end{array}$ \\
\hline$\%$ Peers Foreign-Born $\times$ & $0.720^{* *}$ & $0.601^{+}$ & -0.734 & $0.665^{*}$ & -0.364 \\
\hline \% School Shared Ethnicity & $(0.248)$ & (0.359) & $(0.482)$ & (0.290) & $(0.798)$ \\
\hline$\%$ Peers Foreign-Born $\times$ & $0.401^{* * *}$ & $0.328^{* *}$ & $-0.775^{* *}$ & $0.237^{+}$ & $-1.220^{* * *}$ \\
\hline Student Foreign-Born & $(0.117)$ & (0.119) & $(0.274)$ & (0.138) & $(0.243)$ \\
\hline$\%$ Peers foreign-born $\times$ & $-1.270^{* * *}$ & $-0.986^{*}$ & $2.485^{* *}$ & $-0.807^{+}$ & $1.731^{+}$ \\
\hline $\begin{array}{l}\text { Student Foreign-Born } \times \\
\text { \% School Shared Ethnicity }\end{array}$ & $(0.422)$ & $(0.427)$ & $(0.801)$ & $(0.416)$ & $(1.016)$ \\
\hline $\mathrm{N}$ & 73,482 & 78,239 & 78,546 & 78,065 & 14,082 \\
\hline
\end{tabular}

Note. Coefficient estimates from regressions predicting five outcome measures. Standard errors in parentheses. All specifications include all balancing test controls including race and ethnicity controls, grade and school fixed effects, as well as a control for foreign-born. The first panel presents the baseline peer effect estimates from Table 3. The second panel presents estimates that interact the peer effect variables with a measure of the school level fraction of foreign-born students who share the same race or ethnicity as the current student. Third panel presents similar estimates except that the school fraction foreign born is based on the fraction sharing the same country of origin for Asians and Hispanics and is set to zero otherwise. The models estimated for the third panel also include dummies for each country of origin for the Asian and the Hispanic students. The first four columns based on the wave 1 in-school sample. The final column results for PVT scores based on the wave 1 in-home sample.

$+p<0.10,{ }^{*} p<0.05,{ }^{* *} p<0.01,{ }^{* * *} p<0.001$ 
Appendix. Supplementary Online Material

Figure A1. Proportion of Adolescents’ Same-Cohort Peers that Are Foreign-Born, by Foreign-Born and US-Born Adolescents

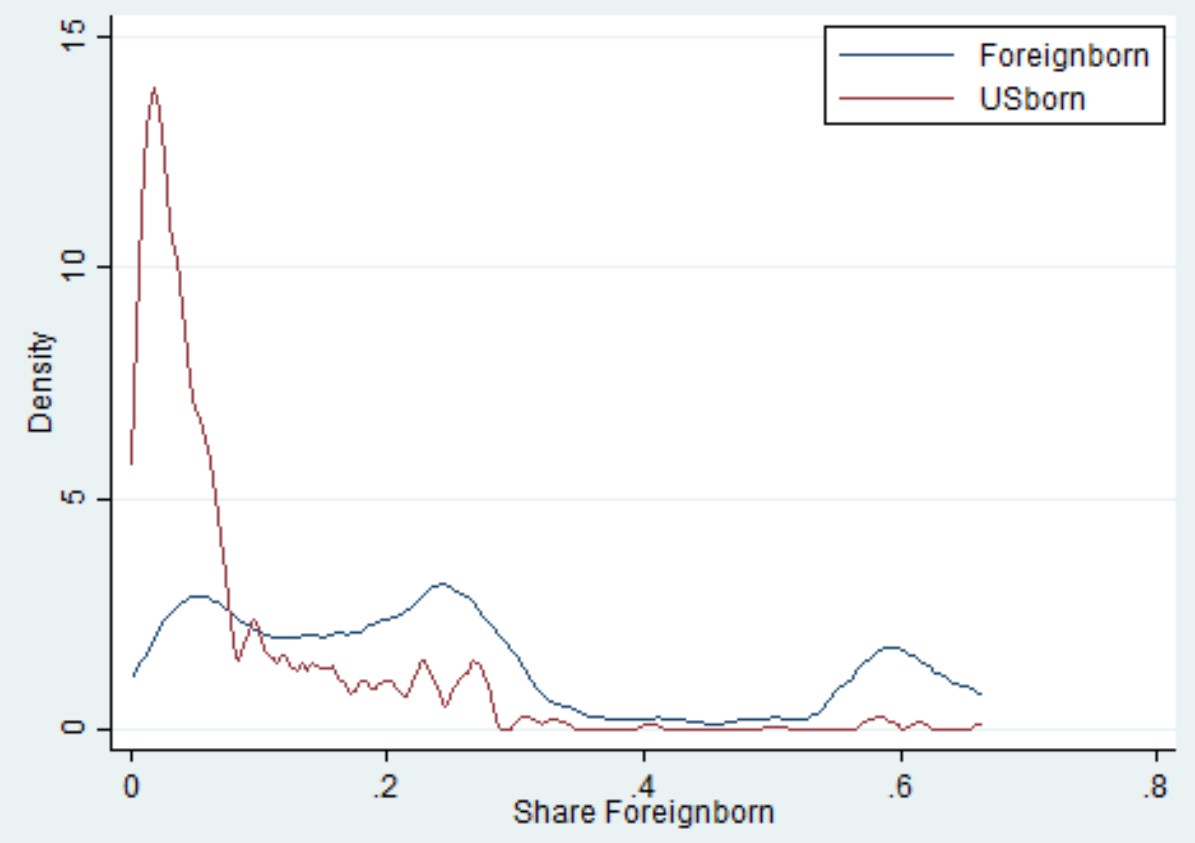


Table A2. Mean Values on Individual Measures Used to Construct Study Outcomes

\begin{tabular}{|c|c|c|c|c|}
\hline & & $\begin{array}{l}\text { US- } \\
\text { Born }\end{array}$ & $\begin{array}{l}\text { Foreign- } \\
\text { Born }\end{array}$ & t-stat \\
\hline \multirow[t]{5}{*}{ Social Acceptance } & Feels close to people at school* & 3.547 & 3.483 & -4.565 \\
\hline & Feels part of school* & 3.537 & 3.438 & -6.497 \\
\hline & Students at school are prejudiced & 2.757 & 2.865 & 7.441 \\
\hline & Happy to be at this school* & 3.539 & 3.624 & 5.475 \\
\hline & Feels socially accepted* & 3.767 & 3.706 & -4.889 \\
\hline \multirow[t]{4}{*}{ Mental Health } & Depressed-last month* & 3.794 & 3.904 & 7.432 \\
\hline & Trouble relaxing-last month* & 4.033 & 4.125 & 6.629 \\
\hline & Moody-last month* & 3.536 & 3.831 & 19.839 \\
\hline & Cried a lot-last month* & 4.253 & 4.235 & -1.414 \\
\hline \multirow[t]{5}{*}{ Health Risk Behavior } & Smoked cigarettes-last 12 months & 1.231 & 0.828 & -16.225 \\
\hline & Drank beer wine liquor-last 12 months & 1.242 & 1.010 & -12.488 \\
\hline & Got drunk-last 12 months & 0.722 & 0.547 & -10.819 \\
\hline & Raced on bike or car-last 12 months & 1.617 & 1.443 & -7.201 \\
\hline & In danger due to dare-last 12 months & 0.861 & 0.656 & -11.433 \\
\hline \multirow[t]{5}{*}{ Academic Effort } & Tries to do school work well* & 3.235 & 3.286 & 6.181 \\
\hline & Time spent watching tv on school day* & 2.694 & 2.759 & 4.910 \\
\hline & Skipped school-last 12 months* & 6.375 & 6.268 & -6.982 \\
\hline & Trouble getting homework done* & 3.225 & 3.049 & -10.629 \\
\hline & Trouble getting along with teacher* & 3.797 & 3.770 & -1.718 \\
\hline \multirow[t]{16}{*}{ Mental Health (W4) } & How often feel isolated* & 2.039 & 2.126 & 2.782 \\
\hline & How often not in control of life* & 1.255 & 1.159 & -2.608 \\
\hline & How often confident to handle prob* & 2.745 & 2.841 & 2.608 \\
\hline & How often things go your way* & 2.809 & 2.831 & 0.631 \\
\hline & How often overwhelmed w. difficulties* & 1.191 & 1.169 & -0.631 \\
\hline & Bothered by things last week* & 2.487 & 2.472 & -0.667 \\
\hline & Blues last week* & 2.687 & 2.655 & -1.499 \\
\hline & Fell as good as others last week* & 2.230 & 2.126 & -3.492 \\
\hline & Trouble concentrating last week* & 2.197 & 2.279 & 3.084 \\
\hline & Depressed last week* & 2.629 & 2.650 & 0.925 \\
\hline & Tired last week* & 2.130 & 2.164 & 1.301 \\
\hline & Happy last week* & 2.171 & 2.156 & -0.568 \\
\hline & Enjoyed life last week* & 2.332 & 2.324 & -0.288 \\
\hline & Sad last week* & 2.439 & 2.463 & 1.088 \\
\hline & Feel disliked last week* & 2.711 & 2.695 & -0.804 \\
\hline & Feel not respected last week* & 2.030 & 2.158 & 4.561 \\
\hline \multirow{4}{*}{$\begin{array}{l}\text { Health Risk Behavior } \\
\text { (W4) }\end{array}$} & Num days smoke last month & 7.857 & 4.123 & -8.824 \\
\hline & Drunk last year & 1.115 & 0.821 & -5.765 \\
\hline & Days smoked marijuana last month & 0.747 & 0.392 & -6.290 \\
\hline & Has used hard drugs & 0.178 & 0.125 & -4.076 \\
\hline \multirow{2}{*}{$\begin{array}{l}\text { Residential Economic } \\
\text { Status (W4) }\end{array}$} & Unemployment rate W4 & 0.920 & 0.927 & 4.556 \\
\hline & Male labor force participation rate $\mathrm{W} 4 *$ & 0.718 & 0.724 & 1.241 \\
\hline
\end{tabular}


Log income per capita W4*

Prop persons in poverty $\mathrm{W} 4 *$

Prop housing vacant W4*

Log median house value W4*

Total adult arrests W4*

Total juvenile arrests W4*

$\begin{array}{ccc}10.064 & 10.079 & 1.122 \\ 0.852 & 0.863 & 3.037 \\ 0.890 & 0.911 & 7.655 \\ 12.054 & 12.508 & 19.039 \\ -543.409 & -476.815 & 6.931 \\ -157.947 & -136.187 & 7.312\end{array}$

Source: Add Health.

Note. * indicates a reverse-coded item. Mean values stratified by students' country of birth. T-statistic on test of difference between group means shown in right column. 
Table A3. Individual Item Loadings from Principle Components

\begin{tabular}{|c|c|c|}
\hline \multirow{5}{*}{ Social Acceptance } & Feels close to people at school* & 0.696 \\
\hline & Feels part of school* & 0.785 \\
\hline & Students at school are prejudiced & 0.121 \\
\hline & Happy to be at this school* & 0.703 \\
\hline & Feels socially accepted* & 0.609 \\
\hline \multirow[t]{4}{*}{ Mental Health } & Depressed-last month* & 0.776 \\
\hline & Trouble relaxing-last month* & 0.669 \\
\hline & Moody-last month* & 0.685 \\
\hline & Cried a lot-last month* & 0.637 \\
\hline \multirow[t]{5}{*}{ Health Risk Behavior } & Smoked cigarettes-last 12 months & 0.613 \\
\hline & Drank beer wine liquor-last 12 months & 0.870 \\
\hline & Got drunk-last 12 months & 0.860 \\
\hline & Raced on bike or car-last 12 months & 0.255 \\
\hline & In danger due to dare-last 12 months & 0.496 \\
\hline \multirow[t]{5}{*}{ Academic Effort } & Tries to do school work well* & 0.263 \\
\hline & Time spent watching tv on school day* & 0.125 \\
\hline & Skipped school-last 12 months* & 0.286 \\
\hline & Trouble getting homework done* & 0.606 \\
\hline & Trouble getting along with teacher* & 0.585 \\
\hline \multirow[t]{16}{*}{ Mental Health (W4) } & How often feel isolated* & 0.526 \\
\hline & How often not in control of life* & -0.777 \\
\hline & How often confident to handle prob* & 0.777 \\
\hline & How often things go your way* & 0.769 \\
\hline & How often overwhelmed w. difficulties* & -0.769 \\
\hline & Bothered by things last week* & 0.509 \\
\hline & Blues last week* & 0.638 \\
\hline & Fell as good as others last week* & 0.449 \\
\hline & Trouble concentrating last week* & 0.458 \\
\hline & Depressed last week* & 0.698 \\
\hline & Tired last week* & 0.388 \\
\hline & Happy last week* & 0.665 \\
\hline & Enjoyed life last week* & 0.646 \\
\hline & Sad last week* & 0.668 \\
\hline & Feel disliked last week* & 0.393 \\
\hline & Feel not respected last week* & 0.378 \\
\hline \multirow[t]{4}{*}{ Health Risk Behavior (W4) } & Num days smoke last month & 0.442 \\
\hline & Drunk last year & 0.435 \\
\hline & Days smoked marijuana last month & 0.525 \\
\hline & Has used hard drugs & 0.549 \\
\hline \multirow[t]{6}{*}{ Residential Economic Status (W4) } & Unemployment rate W4 & 0.676 \\
\hline & Male labor force participation rate $\mathrm{W} 4 *$ & 0.563 \\
\hline & Log income per capita W4* & 0.833 \\
\hline & Prop persons in poverty $\mathrm{W}^{*}$ & 0.816 \\
\hline & Prop housing vacant W4* & 0.469 \\
\hline & Log median house value W4* & 0.628 \\
\hline
\end{tabular}


Note. * indicates a reverse-coded item. 
Table A4. Prediction of Retention in Wave 4 of Add Health, Among Respondents Who Complete the PVT In-Home Tests in Wave 1.

\begin{tabular}{|lc|}
\hline & Observed in Wave 4 \\
\hline \% Peers Foreign-Born & 0.138 \\
\% Peers Foreign-Born $\times$ Student Foreign-Born & $(0.226)$ \\
& 0.184 \\
N & $(0.105)$ \\
R-squared & 13,940 \\
\hline
\end{tabular}

Note: Unstandardized coefficients estimated from Eq. 1, in which the composition of student cohorts in the InHome Wave 1 sample of Add Health are used to predict retention in the study by Wave 4. Grade and school fixed effects, individual and family controls included. 
Table A5. Standard Deviation of Percent Peers Foreign-Born

\begin{tabular}{lcc}
\hline Standard Deviation & Student Native-Born & Student Foreign-Born \\
Unconditional & 0.099 & 0.199 \\
Within School & 0.021 & 0.035 \\
$\mathrm{~N}$ & 78,164 & 8,262 \\
\hline
\end{tabular}


Table A6. Level Estimates of Peer Effects on Student's Outcomes

\begin{tabular}{|c|c|c|c|c|c|c|}
\hline & $\begin{array}{c}\text { Social } \\
\text { Acceptance }\end{array}$ & $\begin{array}{l}\text { Mental } \\
\text { Health }\end{array}$ & $\begin{array}{c}\text { Health Risk } \\
\text { Behavior }\end{array}$ & $\begin{array}{l}\text { Academic } \\
\text { Effort }\end{array}$ & $\begin{array}{c}\text { PVT } \\
\text { Scores }\end{array}$ & \\
\hline & (1) & (2) & (3) & (4) & (5) & \\
\hline$\%$ Peers Foreign-Born $\times$ & 0.077 & -0.258 & 0.212 & -0.238 & 0.084 & \\
\hline Student Native-Born & (0.194) & $(0.168)$ & $(0.289)$ & $(0.209)$ & $(0.364)$ & \\
\hline$\%$ Peers Foreign-Born $\times$ & 0.343 & -0.021 & -0.333 & -0.082 & $-0.946^{*}$ & \\
\hline Student Foreign-Born & $(0.212)$ & $(0.192)$ & $(0.325)$ & $(0.217)$ & $(0.447)$ & \\
\hline $\mathrm{N}$ & 73,482 & 78,239 & 78,546 & 78,065 & 14,082 & \\
\hline & Inor & Montal & Hoolth Dicl & DVT & Vourc of & Residential \\
\hline & $\begin{array}{l}\text { Earnings } \\
\text { (1) }\end{array}$ & $\begin{array}{l}\text { Health } \\
\text { (2) }\end{array}$ & $\begin{array}{l}\text { Behavior } \\
\text { (3) }\end{array}$ & $\begin{array}{c}\text { Scores } \\
\text { (4) }\end{array}$ & $\begin{array}{c}\text { Schooling } \\
\text { (5) }\end{array}$ & $\begin{array}{c}\text { Status } \\
\text { (6) }\end{array}$ \\
\hline$\%$ Peers Foreign-Born $\times$ & 1.268 & 0.214 & 0.108 & 0.074 & 0.492 & -0.339 \\
\hline Student Native-Born & (1.696) & $(0.321)$ & $(0.276)$ & $(0.306)$ & $(0.820)$ & $(0.346)$ \\
\hline$\%$ Peers Foreign-Born $\times$ & 1.550 & 0.288 & -0.092 & -0.370 & -0.232 & -0.372 \\
\hline Student Foreign-Born & $(1.676)$ & (0.339) & $(0.275)$ & $(0.349)$ & $(0.810)$ & $(0.351)$ \\
\hline $\mathrm{N}$ & 11,058 & 11,271 & 11,193 & 10,549 & 11,292 & 11,214 \\
\hline
\end{tabular}

Notes: Coefficient estimates from regressions predicting six outcome measures. Standard errors in parentheses. All specifications include all balancing test controls including race and ethnicity controls, grade and school fixed effects, as well as a control for foreign-born. The first row presents estimates of the interaction of percent foreign born with whether the student is a native. The second row presents estimates of the interaction of percent foreign born with whether the student is foreign-born, capturing the level peer estimate for foreign-born students rather than the difference between foreign and native-born students.

$+p<0.10, * p<0.05,{ }^{* *} p<0.01, * * * p<0.001$ 


\section{Balancing Tests Drawing on Oster (2015)}

We conduct a more formal analysis of deviations from balance using techniques developed by Oster (2015). This method represents an extension of the work by Altonji, Elber and Taber (2005) and is motivated by the idea that there are two key pieces of information necessary to assess the importance of selection: 1 . The sensitivity of the parameter estimates of interest to the inclusion of additional individual level controls, and 2. The explanatory power of those controls as captured by changes in the model R-squared when those controls are added. Oster (2014) develops a test statistic from comparing the model estimates conditional on just the controls required for identification to an expanded model that adds additional individual controls, in our case the same controls that we include in our balancing tests. A test statistic above 1 in magnitude indicates that the selection on unobserved variables has to be stronger than the selection on observables in order to produce an estimated effect of zero. If the controls move the coefficient away from zero, then the test statistic will be negative, and in that case concerns about bias of estimates away from zero only arise if selection on unobserved variables is in the opposite direction to the selection on observed variables. However, a test statistic greater than -1 can be interpreted in the same manner that the selection on unobserved variables has to be stronger than the selection on observables and in the opposite direction in order to produce an estimated effect of zero

The Oster (2015) test is designed to assess one coefficient at a time. Therefore, we begin by examining the stability of the coefficient estimates on the cohort composition variable (percent of foreign-born students in the cohort). We first assess these effects for the full sample, and then for the subsample of US-born students, which is comparable to the US-born student estimates later in the study when we also include an interaction of the composition variable with whether the foreign-born status of individuals. In the second analysis, we estimate a model with both the control for percent foreign-born in cohort and the interaction of percent foreign-born with whether student foreign born using the full sample, and then apply the Oster test to the interaction term.

The results of this investigation are presented in Table A7. The columns present the estimates for the full sample using an uncontrolled model presented in the column labelled 'UC' that includes share foreign born in cohort, school fixed effects, grade indicators, the foreign-born indicator, and the interaction between share foreign born and foreign-born status. The estimates 
presented are the coefficient on the interaction using the full sample, and the test statistics are based on the movements of the interaction coefficient and using a controlled model presented in column 'C' that adds the controls from the balancing tests. Each panel represents a different student outcome variable. The first row shows the R-squared, the second row shows the parameter estimate on share foreign born, and the third row shows the test statistic.

With a few exceptions, the test statistics are above 2.0 and often well above 2.0 implying that the magnitude of selection on unobserved variables would need to be double or more the magnitude of selection on observables in order to imply that our estimates are zero. In columns 1 through 4 on the direct effect of share foreign-born, the exceptions are risky behavior and percent foreign born in wave 4 neighborhood, academic effort and health behavior for the full sample only, and linguistic isolation and percent foreign-born in wave 4 neighborhood and wave 3 test score for the US-born subsample. In the last two columns that examine the interaction with foreign born status, the test statistics near or below 2.0 in magnitude are for human capital investment and the three wave 4 neighborhood variables. However, in every case where the Oster test statistic is near or below 2.0, the magnitudes of the parameter estimates are quite small relative to the other parameter estimates presented in the table. Therefore, the only time that the addition of controls moves the parameter by a substantial share of its value is when that value is small in magnitude. In practice, the Oster statistics for the central results in the paper range between 8.51 and 61.22, suggesting that the study results are robust to all but extremely high levels of selection on unobserved variables. 
Table A7. Oster (2015) Test of Interaction Term of \% Foreign-Born $\times$ Student Foreign-Born

\begin{tabular}{|lccc|}
\hline & & $\mathrm{C}$ & $\mathrm{UC}$ \\
\hline Social Acceptance & $R^{2}$ & 0.058 & 0.044 \\
Mental Health & $\beta$ & 0.265 & 0.263 \\
& $\delta$ & -124.555 & \\
Health Risk Behavior & $R^{2}$ & 0.144 & 0.044 \\
& $\beta$ & 0.236 & 0.230 \\
Academic Effort & $\delta$ & -98.768 & \\
& $R^{2}$ & 0.120 & 0.091 \\
PVT Scores & $\beta$ & -0.545 & -0.534 \\
& $\delta$ & -41.330 & \\
Log Earnings (W4) & $R^{2}$ & 0.065 & 0.035 \\
& $\beta$ & 0.156 & 0.148 \\
Mental Health (W4) & $\delta$ & -31.626 & \\
& $R^{2}$ & 0.322 & 0.261 \\
Health Risk Behavior (W4) & $\beta$ & -1.029 & -0.991 \\
& $\delta$ & -17.025 & \\
PVT Scores (W3) & $R^{2}$ & 0.078 & 0.038 \\
& $\beta$ & 0.281 & 0.282 \\
Years of Schooling (W4) & $\delta$ & 348.774 & \\
& $R^{2}$ & 0.057 & 0.039 \\
Residential Economic Status (W4) & $\beta$ & 0.073 & 0.064 \\
& $\delta$ & -8.987 & \\
& $R^{2}$ & 0.108 & 0.069 \\
\hline & $\beta$ & -0.200 & -0.215 \\
& $\delta$ & 15.642 & \\
& $R^{2}$ & 0.269 & 0.233 \\
& $\beta$ & -0.443 & -0.389 \\
& $\delta$ & -3.609 & \\
& $R^{2}$ & 0.286 & 0.174 \\
& $\beta$ & -0.724 & -0.675 \\
& $\delta$ & -19.670 & \\
& $R^{2}$ & 0.321 & 0.309 \\
& $\delta$ & -0.033 & -0.028 \\
& -0.831 & \\
\hline
\end{tabular}

Note. Testing robustness of the coefficient on the foreign-born indicator interacted with \% foreign-born students in the cohort under the null of zero effect. All specifications include school fixed effects, indicator for the grade attended, indicator for the foreign-born status and \% foreign-born in the cohort. In addition, C models control for gender, age, mother's college attainment, father's college attainment, the indicator that either parent works for pay, that either parent is in professional occupation, and that student lives with both parents, and household size; when this information is missing, the value is imputed with zero and the indicator variable was included to indicate that the imputation was used. Maximum $R^{2}$ is set as 1.3 times $R^{2}$ of the C model. See Oster (2015) for details. W1, W3 and W4 indicate surveys waves I, III and IV respectively. 
Table A8. Conditional Correlations between Peer Attributes and Student’s Outcomes

\begin{tabular}{|c|c|c|c|c|c|c|}
\hline & $\begin{array}{c}\text { Social } \\
\text { Acceptance }\end{array}$ & $\begin{array}{l}\text { Mental } \\
\text { Health }\end{array}$ & $\begin{array}{c}\text { Health Risk } \\
\text { Behavior }\end{array}$ & $\begin{array}{c}\text { Academic } \\
\text { Effort }\end{array}$ & $\begin{array}{c}\text { PVT } \\
\text { Scores } \\
\end{array}$ & \\
\hline $\begin{array}{l}\text { \% Peers Foreign-Born } \\
\% \text { Peers Foreign-Born } \times \\
\text { Student Foreign-Born }\end{array}$ & $\begin{array}{c}(1) \\
0.004 \\
(0.097) \\
0.430^{* * *} \\
(0.110)\end{array}$ & $\begin{array}{c}(2) \\
0.130^{*} \\
(0.065) \\
0.283^{* *} \\
(0.090)\end{array}$ & $\begin{array}{c}(3) \\
-0.358^{*} \\
(0.163) \\
-0.638^{* *} \\
(0.192)\end{array}$ & $\begin{array}{c}(4) \\
-0.250^{+} \\
(0.134) \\
0.419^{* * *} \\
(0.120)\end{array}$ & $\begin{array}{c}(5) \\
-0.258 \\
(0.196) \\
-0.916^{* * *} \\
(0.250)\end{array}$ & \\
\hline $\mathrm{N}$ & 73,482 & 78,239 & 78,546 & 78,065 & 14,082 & \\
\hline $\begin{array}{l}\text { \% Peers Foreign-Born } \\
\% \text { Peers Foreign-Born } \times \\
\text { Student Foreign-Born }\end{array}$ & $\begin{array}{c}\text { Log } \\
\text { Earnings } \\
(1) \\
0.802^{* *} \\
(0.262) \\
0.256 \\
(0.409)\end{array}$ & $\begin{array}{c}\text { Mental } \\
\text { Health } \\
(2) \\
0.035 \\
(0.156) \\
0.450^{* *} \\
(0.153)\end{array}$ & $\begin{array}{c}\text { Health Risk } \\
\text { Behavior } \\
(3) \\
-0.206^{+} \\
(0.109) \\
-0.346^{*} \\
(0.138)\end{array}$ & $\begin{array}{c}\text { PVT } \\
\text { Scores } \\
(4) \\
-0.637 \\
(0.532) \\
-0.106 \\
(0.428)\end{array}$ & $\begin{array}{c}\text { Years of } \\
\text { Schooling } \\
(5) \\
0.327 \\
(0.418) \\
-0.658^{+} \\
(0.347)\end{array}$ & $\begin{array}{c}\text { Residential } \\
\text { Economic } \\
\text { Status } \\
(6) \\
0.835^{+} \\
(0.501) \\
-0.942^{*} \\
(0.377)\end{array}$ \\
\hline $\mathrm{N}$ & 11,058 & 11,271 & 11,193 & 10,549 & 11,292 & 11,214 \\
\hline
\end{tabular}

Notes: Coefficient estimates from regressions predicting six outcome measures. Standard errors in parentheses. All specifications include grade fixed effects, as well as a control for foreign-born. School fixed effects are omitted so that the estimates contain comparisons across schools. The second panel presents estimates after adding controls for the race and ethnicity variables, and the third panel estimates based on adding all controls listed in Table 2 above. All columns based on the wave 4 sample, except for the fourth column results for PVT score that are based on the wave 3 sample.

$+p<0.10, * p<0.05,{ }^{* *} p<0.01, * * * p<0.001$ 
Table A9. First and Second-Generation Peer Effects on Student's Short-Term Outcomes

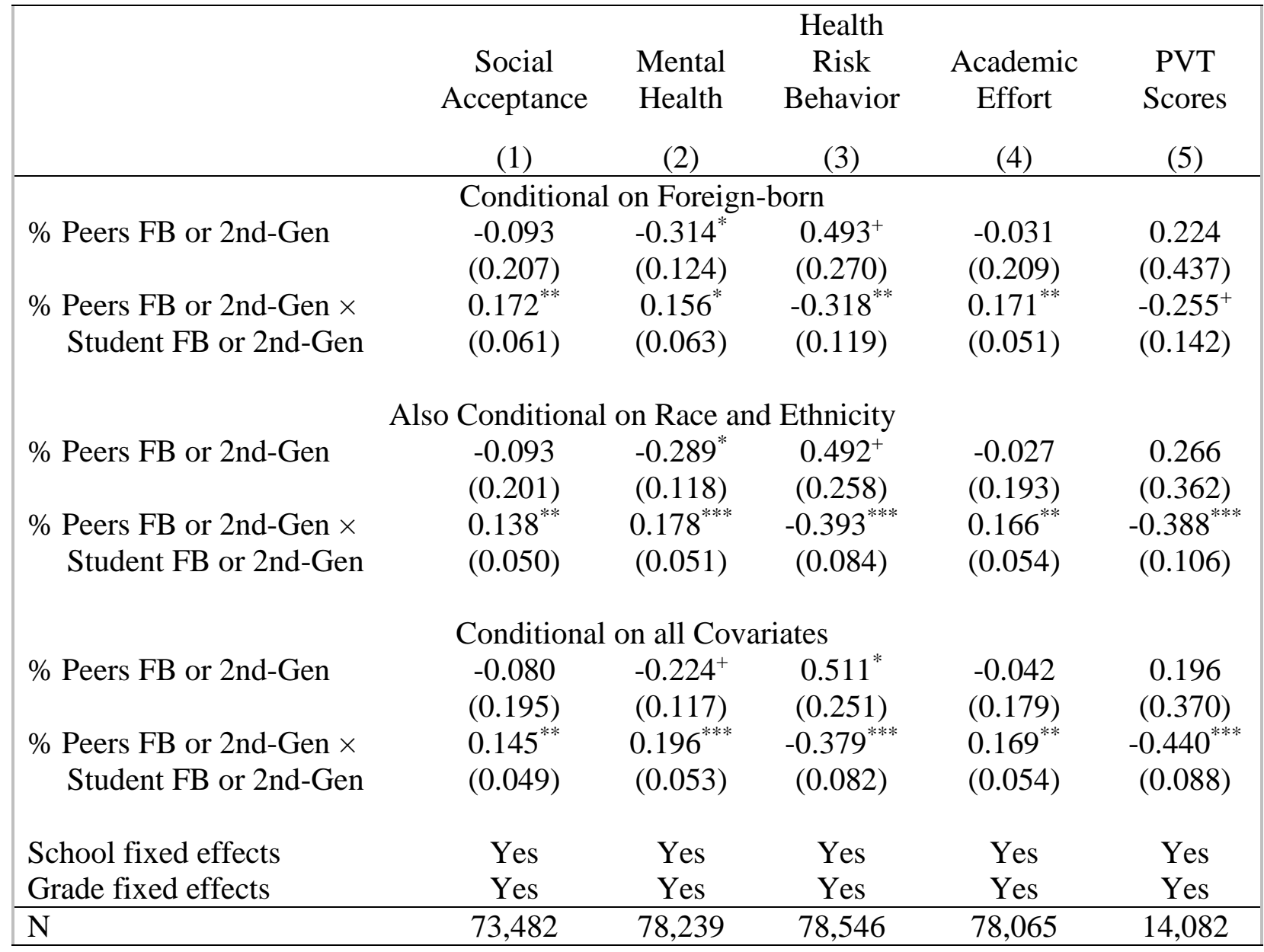

Note. Coefficient estimates from regressions predicting five outcome measures. Standard errors in parentheses. All specifications include grade and school fixed effects, as well as a control for whether student or at least one parent foreignborn. The second panel presents estimates after adding controls for the race and ethnicity variables, and the third panel estimates based on adding all controls listed in Table 2 above. The first four columns based on the wave 1 in-school sample. The final column results for PVT scores based on the wave 1 in-home sample.

$+p<0.10, * p<0.05, * * p<0.01$, *** $p<0.001$ 
Table A10. First and Second-Generation Peer Effects on Student’s Long-Term Outcomes

\begin{tabular}{|c|c|c|c|c|c|c|}
\hline & $\begin{array}{l}\text { Log } \\
\text { Earnings } \\
\quad(1)\end{array}$ & $\begin{array}{l}\text { Mental } \\
\text { Health } \\
\text { (2) }\end{array}$ & $\begin{array}{c}\text { Health } \\
\text { Risk } \\
\text { Behavior } \\
\text { (3) }\end{array}$ & $\begin{array}{l}\text { PVT } \\
\text { Scores } \\
(4)\end{array}$ & $\begin{array}{c}\text { Years of } \\
\text { Schooling } \\
\text { (5) }\end{array}$ & $\begin{array}{c}\text { Residential } \\
\text { Economic } \\
\text { Status } \\
(6)\end{array}$ \\
\hline \multicolumn{7}{|c|}{ Conditional on Foreign-born } \\
\hline \% Peers FB or 2nd-Gen & $\begin{array}{c}0.204 \\
(0.978)\end{array}$ & $\begin{array}{c}0.039 \\
(0.244)\end{array}$ & $\begin{array}{c}0.391^{+} \\
(0.222)\end{array}$ & $\begin{array}{l}-0.014 \\
(0.366)\end{array}$ & $\begin{array}{c}-0.176 \\
(0.631)\end{array}$ & $\begin{array}{l}-0.115 \\
(0.360)\end{array}$ \\
\hline $\begin{array}{l}\% \text { Peers FB or } 2 \text { nd-Gen } \times \\
\text { Student FB or } 2 \text { nd-Gen }\end{array}$ & $\begin{array}{c}0.280 \\
(0.332)\end{array}$ & $\begin{array}{l}-0.007 \\
(0.096)\end{array}$ & $\begin{array}{l}-0.137^{+} \\
(0.079)\end{array}$ & $\begin{array}{c}0.401 \\
(0.360)\end{array}$ & $\begin{array}{c}0.092 \\
(0.198)\end{array}$ & $\begin{array}{c}0.166 \\
(0.116)\end{array}$ \\
\hline \multicolumn{7}{|c|}{ Also Conditional on Race and Ethnicity } \\
\hline$\%$ Peers FB or 2nd-Gen & $\begin{array}{c}0.193 \\
(0.992)\end{array}$ & $\begin{array}{c}0.048 \\
(0.246)\end{array}$ & $\begin{array}{c}0.382^{+} \\
(0.217)\end{array}$ & $\begin{array}{l}-0.032 \\
(0.281)\end{array}$ & $\begin{array}{c}-0.141 \\
(0.620)\end{array}$ & $\begin{array}{l}-0.131 \\
(0.300)\end{array}$ \\
\hline $\begin{array}{l}\% \text { Peers FB or } 2 \text { nd-Gen } \times \\
\text { Student FB or } 2 \text { nd-Gen }\end{array}$ & $\begin{array}{c}0.294 \\
(0.341)\end{array}$ & $\begin{array}{l}-0.080 \\
(0.094)\end{array}$ & $\begin{array}{l}-0.191^{* *} \\
(0.072)\end{array}$ & $\begin{array}{c}0.216 \\
(0.271)\end{array}$ & $\begin{array}{c}0.098 \\
(0.202)\end{array}$ & $\begin{array}{l}-0.009 \\
(0.116)\end{array}$ \\
\hline \multicolumn{7}{|c|}{ Conditional on all Covariates } \\
\hline \% Peers FB or 2nd-Gen & $\begin{array}{c}0.050 \\
(0.932)\end{array}$ & $\begin{array}{c}0.006 \\
(0.240)\end{array}$ & $\begin{array}{l}0.388^{+} \\
(0.216)\end{array}$ & $\begin{array}{l}-0.061 \\
(0.255)\end{array}$ & $\begin{array}{l}-0.517 \\
(0.528)\end{array}$ & $\begin{array}{l}-0.186 \\
(0.285)\end{array}$ \\
\hline $\begin{array}{l}\% \text { Peers FB or } 2 \text { nd-Gen } \times \\
\text { Student FB or } 2 \text { nd-Gen }\end{array}$ & $\begin{array}{c}0.275 \\
(0.304)\end{array}$ & $\begin{array}{l}-0.071 \\
(0.090)\end{array}$ & $\begin{array}{l}-0.197^{*} \\
(0.090)\end{array}$ & $\begin{array}{c}0.180 \\
(0.277)\end{array}$ & $\begin{array}{c}0.136 \\
(0.193)\end{array}$ & $\begin{array}{l}-0.009 \\
(0.108)\end{array}$ \\
\hline $\mathrm{N}$ & 11,058 & 11,271 & 11,193 & 10,549 & 11,292 & 11,214 \\
\hline
\end{tabular}

Note. Coefficient estimates from regressions predicting five outcome measures. Standard errors in parentheses. All specifications include grade and school fixed effects, as well as a control for whether student or at least one parent foreignborn. The second panel presents estimates after adding controls for the race and ethnicity variables, and the third panel estimates based on adding all controls listed in Table 2 above. All columns based on the wave 4 sample, except for the fourth column results for PVT scores that are based on the wave 3 sample.

$+p<0.10, * p<0.05,{ }^{* *} p<0.01,{ }^{* * *} p<0.001$ 
Table A11. Role of Percent Foreign Born Same Subgroup on Student’s Long-Term Outcomes

\begin{tabular}{|c|c|c|c|c|c|c|}
\hline & $\begin{array}{c}\text { Log } \\
\text { Earnings } \\
(1)\end{array}$ & $\begin{array}{c}\text { Mental } \\
\text { Health } \\
(2)\end{array}$ & $\begin{array}{c}\text { Health } \\
\text { Risk } \\
\text { Behavior } \\
\text { (3) }\end{array}$ & $\begin{array}{c}\text { PVT } \\
\text { Scores } \\
(4)\end{array}$ & $\begin{array}{l}\text { Years of } \\
\text { Schooling } \\
\text { (5) }\end{array}$ & $\begin{array}{c}\text { Residential } \\
\text { Economic } \\
\text { Status } \\
(6)\end{array}$ \\
\hline \multicolumn{7}{|c|}{ Baseline Peer Effects } \\
\hline \% Peers Foreign-Born & $\begin{array}{c}1.268 \\
(1.696)\end{array}$ & $\begin{array}{c}0.214 \\
(0.321)\end{array}$ & $\begin{array}{c}0.108 \\
(0.276)\end{array}$ & $\begin{array}{c}0.074 \\
(0.306)\end{array}$ & $\begin{array}{c}0.492 \\
(0.820)\end{array}$ & $\begin{array}{l}-0.339 \\
(0.346)\end{array}$ \\
\hline $\begin{array}{l}\text { \% Peers Foreign-Born } \times \\
\% \text { School Shared Ethnicity }\end{array}$ & $\begin{array}{c}0.282 \\
(0.390)\end{array}$ & $\begin{array}{c}0.073 \\
(0.127)\end{array}$ & $\begin{array}{l}-0.201^{*} \\
(0.101)\end{array}$ & $\begin{array}{l}-0.444^{* *} \\
(0.144)\end{array}$ & $\begin{array}{l}-0.724^{* *} \\
(0.250)\end{array}$ & $\begin{array}{l}-0.033 \\
(0.138)\end{array}$ \\
\hline \multicolumn{7}{|c|}{ Peer Effects by \% Shared Race and Ethnicity } \\
\hline \% Peers Foreign-Born & $\begin{array}{c}0.346 \\
(0.331)\end{array}$ & $\begin{array}{c}0.111 \\
(0.322)\end{array}$ & $\begin{array}{c}0.157 \\
(0.291)\end{array}$ & $\begin{array}{l}-0.129 \\
(0.299)\end{array}$ & $\begin{array}{l}-0.409 \\
(0.392)\end{array}$ & $\begin{array}{c}0.910 \\
(0.872)\end{array}$ \\
\hline $\begin{array}{l}\% \text { Peers Foreign-Born } \times \\
\% \text { School Shared Ethnicity }\end{array}$ & $\begin{array}{l}-0.163 \\
(0.219)\end{array}$ & $\begin{array}{c}0.254 \\
(0.263)\end{array}$ & $\begin{array}{l}-0.130 \\
(0.194)\end{array}$ & $\begin{array}{c}0.492 \\
(0.301)\end{array}$ & $\begin{array}{c}0.107 \\
(0.362)\end{array}$ & $\begin{array}{l}-0.968 \\
(0.656)\end{array}$ \\
\hline $\begin{array}{l}\% \text { Peers Foreign-Born } \times \\
\text { Student Foreign-Born }\end{array}$ & $\begin{array}{c}0.087 \\
(0.233)\end{array}$ & $\begin{array}{c}0.091 \\
(0.397)\end{array}$ & $\begin{array}{l}-0.243 \\
(0.241)\end{array}$ & $\begin{array}{l}-0.584 \\
(0.615)\end{array}$ & $\begin{array}{c}0.043 \\
(0.487)\end{array}$ & $\begin{array}{l}-1.174 \\
(0.824)\end{array}$ \\
\hline $\begin{array}{l}\text { \% Peers Foreign-Born } \times \\
\text { Student Foreign-Born } \times \\
\% \text { School Shared Ethnicity }\end{array}$ & $\begin{array}{c}-0.091 \\
(0.322)\end{array}$ & $\begin{array}{c}-0.023 \\
(0.507)\end{array}$ & $\begin{array}{c}0.099 \\
(0.338)\end{array}$ & $\begin{array}{c}0.190 \\
(0.829)\end{array}$ & $\begin{array}{c}0.082 \\
(0.562)\end{array}$ & $\begin{array}{l}0.688 \\
(1.012)\end{array}$ \\
\hline \multicolumn{7}{|c|}{ Peer Effects by Shared Country of Origin for Hispanics and Asians } \\
\hline \% Peers Foreign-Born & $\begin{array}{c}1.126 \\
(1.547)\end{array}$ & $\begin{array}{c}0.122 \\
(0.333)\end{array}$ & $\begin{array}{c}0.140 \\
(0.286)\end{array}$ & $\begin{array}{l}-0.102 \\
(0.281)\end{array}$ & $\begin{array}{c}0.426 \\
(0.751)\end{array}$ & $\begin{array}{l}-0.359 \\
(0.372)\end{array}$ \\
\hline $\begin{array}{l}\% \text { Peers Foreign-Born } \times \\
\% \text { School Shared Ethnicity }\end{array}$ & $\begin{array}{l}4.080^{*} \\
(2.024)\end{array}$ & $\begin{array}{l}1.314^{* *} \\
(0.500)\end{array}$ & $\begin{array}{l}-0.455 \\
(0.445)\end{array}$ & $\begin{array}{c}2.400 \\
(1.519)\end{array}$ & $\begin{array}{c}1.602 \\
(1.127)\end{array}$ & $\begin{array}{c}0.678 \\
(0.800)\end{array}$ \\
\hline$\%$ Peers Foreign-Born $\times$ & -0.125 & 0.447 & $-0.447^{*}$ & -0.183 & 0.011 & 0.338 \\
\hline Student Foreign-Born & (0.974) & $(0.282)$ & $(0.203)$ & (0.290) & (0.552) & $(0.283)$ \\
\hline $\begin{array}{l}\% \text { Peers Foreign-Born } \times \\
\text { Student Foreign-Born } \times \\
\% \text { School Shared Ethnicity }\end{array}$ & $\begin{array}{c}0.209 \\
(3.399)\end{array}$ & $\begin{array}{l}-1.646^{*} \\
(0.819)\end{array}$ & $\begin{array}{l}1.352^{+} \\
(0.722)\end{array}$ & $\begin{array}{l}-1.239 \\
(1.289)\end{array}$ & $\begin{array}{l}-2.510 \\
(1.690)\end{array}$ & $\begin{array}{l}-1.590 \\
(1.145)\end{array}$ \\
\hline $\mathrm{N}$ & 11,058 & 11,271 & 11,193 & 10,549 & 11,292 & 11,214 \\
\hline
\end{tabular}

Note. Coefficient estimates from regressions predicting six outcome measures. Standard errors in parentheses. All specifications include all balancing test controls including race and ethnicity controls, grade and school fixed effects, as well as a control for foreign-born. The first panel presents the baseline peer effect estimates from Table 3. The second panel presents estimates that interact the peer effect variables with a measure of the school level fraction of foreign-born students who share the same race or ethnicity as the current student. Third panel presents similar estimates except that the school fraction foreign born is based on the fraction sharing the same country of origin for Asians and Hispanics and is set to zero otherwise. The models estimated for the third panel also include dummies for each country of origin for the Asian and the Hispanic students. The first four columns based on the wave 1 in-school sample. The final column results for PVT scores based on the wave 1 in-home sample.

$+p<0.10, * p<0.05, * * p<0.01, * * * p<0.001$ 
Table A12. Peer Effects on Foreign-Born Student’s Short-Term Outcomes by School Attributes

\begin{tabular}{|c|c|c|c|c|c|}
\hline & $\begin{array}{c}\text { Social } \\
\text { Acceptance } \\
(1)\end{array}$ & $\begin{array}{c}\text { Mental } \\
\text { Health } \\
(2)\end{array}$ & $\begin{array}{c}\text { Health } \\
\text { Risk } \\
\text { Behavior } \\
\text { (3) }\end{array}$ & $\begin{array}{c}\text { Academic } \\
\text { Effort } \\
(4)\end{array}$ & $\begin{array}{c}\text { PVT } \\
\text { Scores } \\
(5) \\
\end{array}$ \\
\hline \multicolumn{6}{|c|}{ School Percent Foreign-Born Above Median } \\
\hline$\%$ Peers Foreign-Born $\times$ & -1.591 & $2.464^{+}$ & -2.704 & 0.988 & -7.313 \\
\hline Studen & (1.701) & (1.328) & (2.824) & (2.071) & (5.012) \\
\hline \% Peers Foreig & 1.746 & -2.33 & 2.441 & -0.939 & 6.430 \\
\hline Student Foreign-Born $\times$ & $(1.70$ & $(1.33$ & (2.827) & $(2.071)$ & $(5.021)$ \\
\hline \multirow{2}{*}{\multicolumn{6}{|c|}{$\begin{array}{l}\text { School Level Dummy } \\
\text { School Percent Non-English Sneaking at Home Above Median }\end{array}$}} \\
\hline & & & \multicolumn{3}{|c|}{ School Percent Non-English Speaking at Home Above Median } \\
\hline$\%$ Peers Foreign-Born $\times$ & $0.975^{+}$ & $1.359^{* * *}$ & $-2.557^{* * *}$ & $1.215^{* * *}$ & $-8.724^{*}$ \\
\hline Foreign-Born & (0.519) & $(0.311)$ & $(0.479)$ & $(0.268)$ & (3.774) \\
\hline$\%$ Peers Foreign-Born $\times$ & -0.823 & $-1.265^{* * *}$ & $2.294^{* * *}$ & $-1.190^{* * *}$ & $7.867^{*}$ \\
\hline Student Foreign-Born $\times$ & $(0.525)$ & $(0.318)$ & $(0.506)$ & $(0.274)$ & (3.785) \\
\hline \multicolumn{6}{|c|}{ School Percent Second Generation Above Median } \\
\hline$\%$ Peers Foreign-Born $\times$ & -0.230 & $2.636^{* *}$ & -1.626 & $1.899^{* *}$ & -2.659 \\
\hline & $(0.939)$ & & $(1.425)$ & & $(2.704)$ \\
\hline \% Peers Foreign-Born × & 0.354 & -2.481 & 1.317 & $-1.808^{* *}$ & 1.897 \\
\hline Student Foreign-Born $\times$ & (0.944) & (0.909) & (1.440) & (0.589) & (2.715) \\
\hline School Level Dummy & & & & & \\
\hline \multicolumn{6}{|c|}{ At Least One Student Who Completed Survey in Language Other than Engl } \\
\hline$\%$ Peers Foreign-Born $\times$ & 0.092 & 0.366 & $-1.149^{*}$ & 0.221 & $-2.469^{* *}$ \\
\hline & $(0.657)$ & & (0.499) & $(0.372)$ & $(0.707)$ \\
\hline \% Peers Foreign-Born $\times$ & 0.087 & -0.125 & 0.767 & -0.056 & $1.728^{*}$ \\
\hline $\begin{array}{l}\text { Student Foreign-Born } \times \\
\text { School Level Dummy }\end{array}$ & $(0.661)$ & $(0.582)$ & $(0.552)$ & $(0.384)$ & $(0.735)$ \\
\hline $\mathrm{N}$ & 73,482 & 78,239 & 78,546 & 78,065 & 14,082 \\
\hline
\end{tabular}

Note. Coefficient estimates for the foreign-born student interactions from regressions predicting five outcome measures. Standard errors in parentheses. All specifications include balancing test controls, grade and school fixed effects, as well as a control for foreign-born. The first three panels test whether the foreign-born interaction varies based on whether the school has a fraction of students above the median who are foreign born, who do not speak English at home or who are second generation immigrants based on one or more parent not being born in the U.S, respectively. The final panel divides schools between those where all students completed in the in-home survey in English and schools where at least one student did not complete the in-home survey in English. The first four columns based on the wave 1 in-school sample. The final column results for PVT scores based on the wave 1 in-home sample.

$+p<0.10,{ }^{*} p<0.05,{ }^{* *} p<0.01,{ }^{* * *} p<0.001$ 
Table A13. Peer Effects on Native Student’s Short-Term Outcomes by School Attributes

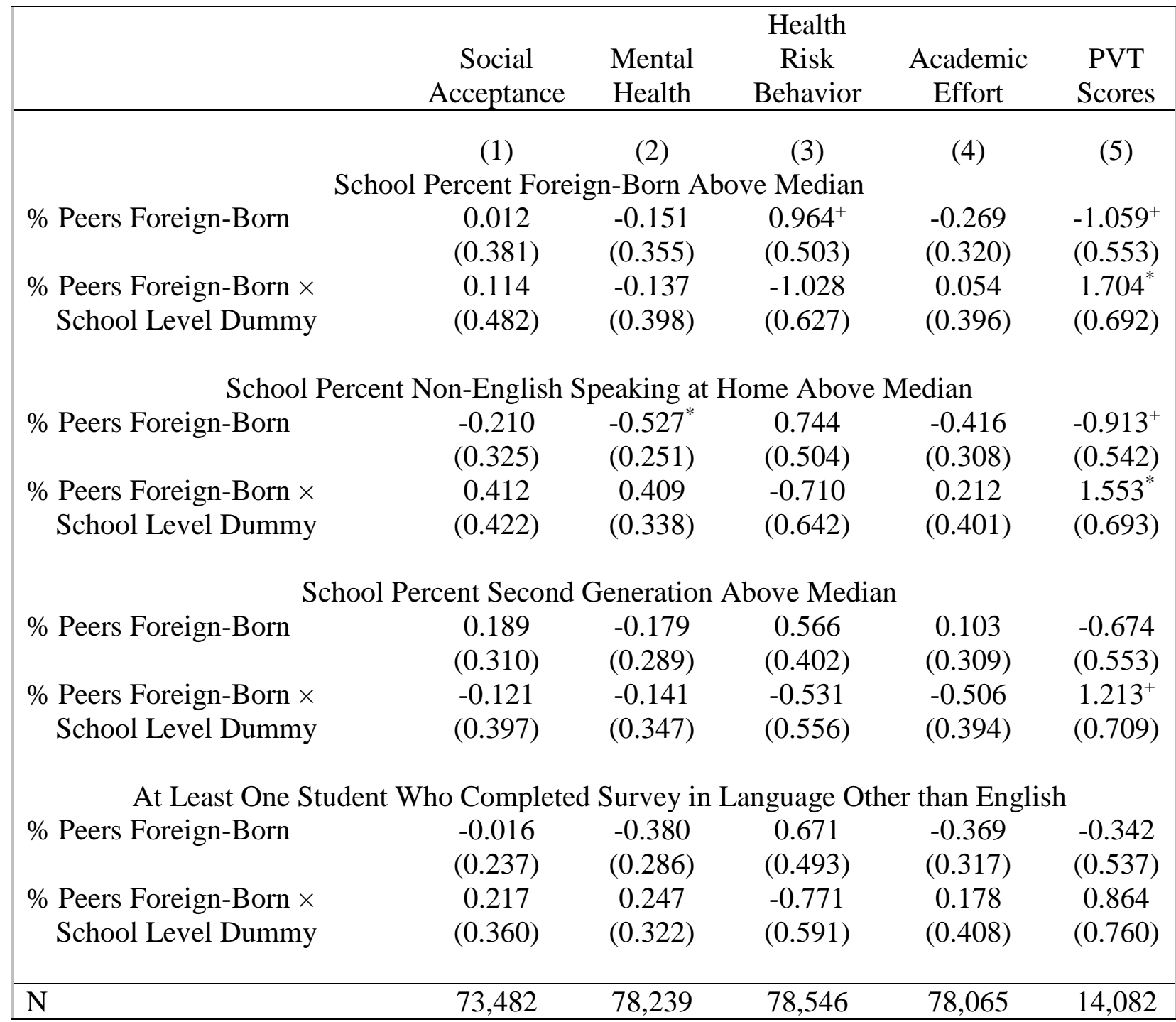

Note. Coefficient estimates for the native-born students from regressions predicting five outcome measures. Standard errors in parentheses. All specifications include balancing test controls, grade and school fixed effects, as well as a control for foreign-born. The first three panels test whether the native-born effect varies based on whether the school has a fraction of students above the median who are foreign born, who do not speak English at home or who are second generation immigrants based on one or more parent not being born in the U.S, respectively. The final panel divides schools between those where all students completed in the in-home survey in English and schools where at least one student did not complete the in-home survey in English. The first four columns based on the wave 1 in-school sample. The final column results for PVT scores based on the wave 1 in-home sample.

$+p<0.10,{ }^{*} p<0.05,{ }^{* *} p<0.01,{ }^{* * *} p<0.001$ 
Table A14. Peer Effects on Foreign-Born Student's Long-Term Outcomes by School Attributes

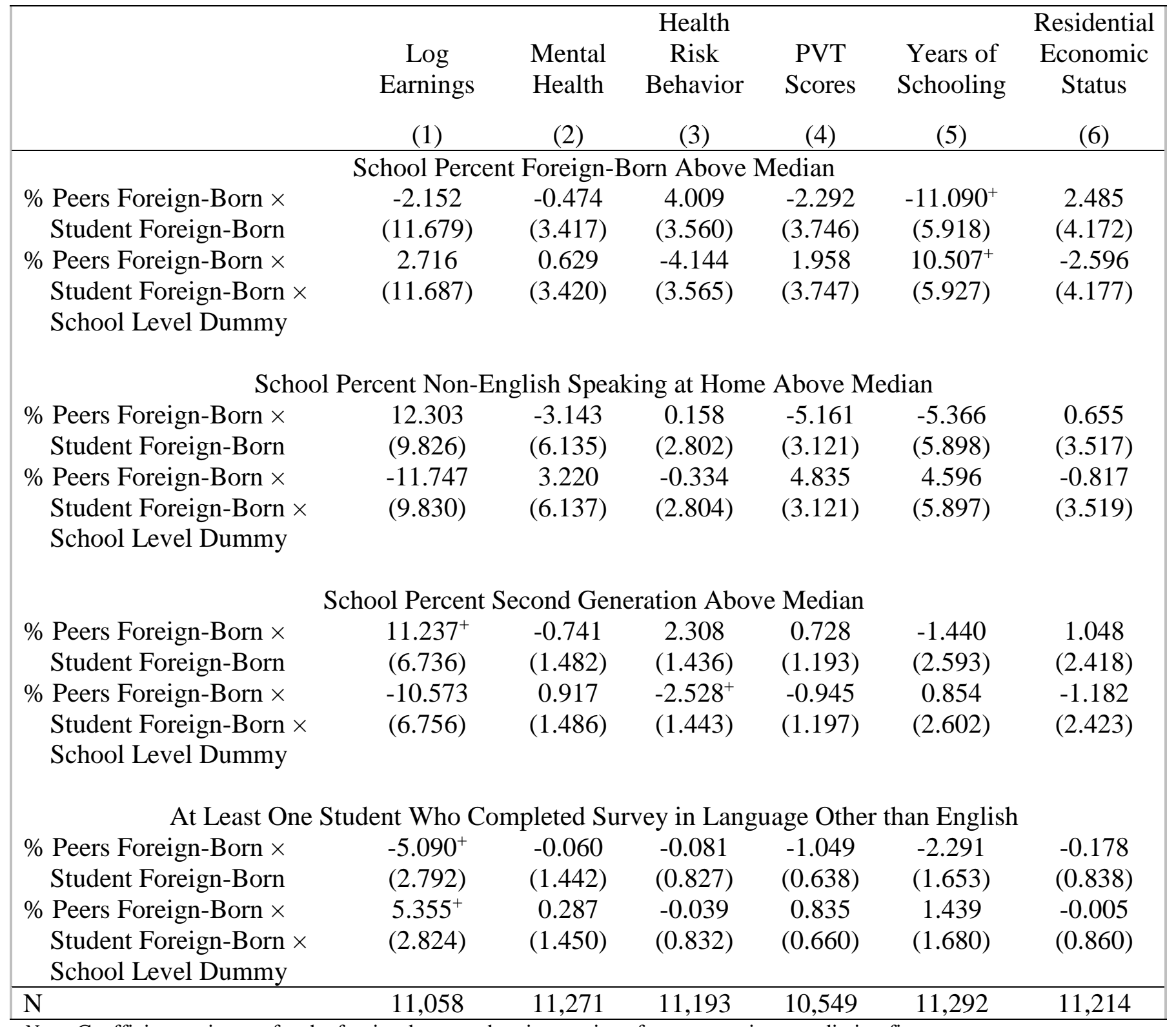

Note. Coefficient estimates for the foreign-born student interactions from regressions predicting five outcome measures. Standard errors in parentheses. All specifications include balancing test controls, grade and school fixed effects, as well as a control for foreign-born. The first three panels test whether the foreign-born interaction varies based on whether the school has a fraction of students above the median who are foreign born, who do not speak English at home or who are second generation immigrants based on one or more parent not being born in the U.S, respectively. The final panel divides schools between those where all students completed in the in-home survey in English and schools where at least one student did not complete the in-home survey in English. All columns based on the wave 4 sample, except for the fourth column results for PVT scores that are based on the wave 3 sample.

$+p<0.10, * p<0.05, * * p<0.01, * * * p<0.001$ 
Table A15. Characteristics of the US Foreign-born Adolescent Population in 1990, 2000, 2012-2017

\begin{tabular}{|c|c|c|c|}
\hline & $\begin{array}{c}1990 \\
\text { 5\% Census }\end{array}$ & $\begin{array}{c}2000 \\
\text { 5\% Census } \\
\end{array}$ & $\begin{array}{c}\text { 2012-2017 } \\
\text { 5\% ACS 5-year }\end{array}$ \\
\hline$\%$ adolescents age $12-18$ who are foreign-born & $7.54 \%(.26)$ & $8.64 \%(.28)$ & $7.26 \%(.26)$ \\
\hline in CA, TX, IL, NY, FL & $14.43 \%(.35)$ & $14.1 \%(.35)$ & $10.0 \%(.3)$ \\
\hline in all other states & $3.85 \%(.19)$ & $5.54 \%(.23)$ & $5.65 \%(.23)$ \\
\hline \multicolumn{4}{|l|}{ Among foreign-born adolescents (age 12-18) } \\
\hline Mean Age (in years) & $15.32(2.01)$ & $15.28(2)$ & $15.4(1.99)$ \\
\hline$\%$ male & $52.28 \%(.5)$ & $52.91 \%(.5)$ & $50.5 \%(.5)$ \\
\hline \% Enrolled in school & $86.63 \%(.34)$ & $86.89 \%(.34)$ & $92.74 \%(.26)$ \\
\hline \% Employed & $30.61 \%(.46)$ & $30.61 \%(.46)$ & 19.3\% (.39) \\
\hline Mean number of family members in household & $5.05(2.28)$ & $4.99(2.25)$ & $4.49(1.94)$ \\
\hline Mean education of head of household (years) & $10.6(5.3)$ & $10.69(5.28)$ & $12.26(4.61)$ \\
\hline
\end{tabular}

Top 10 countries of origin:

$\begin{array}{rccc}1 & \text { Mexico } & \text { Mexico } & \text { Mexico } \\ 2 & \text { Vietnam } & \text { Germany } & \text { China } \\ 3 & \text { Puerto Rico } & \text { Puerto Rico } & \text { Puerto Rico } \\ 4 & \text { Philippines } & \text { Philippines } & \text { Philippines } \\ 5 & \text { Korea } & \text { Korea } & \text { DR } \\ 6 & \text { El Salvador } & \text { Vietnam } & \text { India } \\ 7 & \text { Germany } & \text { DR } & \text { El Salvador } \\ 8 & \text { Canada } & \text { El Salvador } & \text { Guatemala } \\ 9 & \text { Laos } & \text { India } & \text { Korea } \\ 10 & \text { Jamaica } & \text { Canada } & \text { Germany }\end{array}$

Source: PUMS USA.

Note: Mean values with standard deviations in parentheses. Mean education in years calculated by assigning midpoint values of years of schooling to education ranges for less than high school. Higher education programs reported in degrees completed; years assigned as associate degree $=14$ years, bachelor degree $=16$, master degree $=18$, professional degree $=19$ years, $\mathrm{PhD}=20$ years. 